Technological University Dublin

DÜBLIN

ARROW@TU Dublin

2018

\title{
Effects of Nonthermal Plasma Technology on Functional Food Components
}

Aliyu Idris Muhammad

Zhejiang University, Department of Food Science and Nutrition, Hangzhou, China

Xinyu Liao

Zhejiang University, Department of Food Science and Nutrition, Hangzhou, China

Patrick Cullen

Technological University Dublin, pj.cullen@tudublin.ie

See next page for additional authors

Follow this and additional works at: https://arrow.tudublin.ie/schfsehart

Part of the Medicine and Health Sciences Commons

\section{Recommended Citation}

Muhammad, I.M., Liao, X. \& Cullen, P. (2018). Effects of Nonthermal Plasma Technology on Functional Food Components. Comprehensive Reviews in Food Science and Food Safety, vol. 17, no. 5, pg.

1379-1394. doi:10.1111/1541-4337.12379

This Article is brought to you for free and open access by the School of Food Science and Environmental Health at ARROW@TU Dublin. It has been accepted for inclusion in Articles by an authorized administrator of ARROW@TU Dublin. For more information, please contact arrow.admin@tudublin.ie, aisling.coyne@tudublin.ie, gerard.connolly@tudublin.ie.

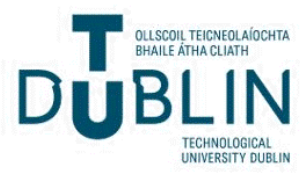




\section{Authors}

Aliyu Idris Muhammad, Xinyu Liao, Patrick Cullen, Donghong Liu, Qisen Xiang, Jun Wang, Shiguo Chen, Xingqian Ye, and Tian Ding 


\title{
Effects of Nonthermal Plasma Technology on Functional Food Components
}

\author{
Aliyu Idris Muhammad (D, Xinyu Liao, Patrick J. Cullen, Donghong Liu (D, Qisen Xiang, Jun Wang, Shiguo Chen, Xingqian Ye, \\ and Tian Ding (i)
}

\begin{abstract}
Understanding the impact of nonthermal plasma (NTP) technology on key nutritional and functional food components is of paramount importance for the successful adoption of the technology by industry. NTP technology (NTPT) has demonstrated marked antimicrobial efficacies with good retention of important physical, chemical, sensory, and nutritional parameters for an array of food products. This paper presents the influence of NTPT on selected functional food components with a focus on low-molecular-weight bioactive compounds and vitamins. We discuss the mechanisms of bioactive compound alteration by plasma-reactive species and classify their influence on vitamins and their antioxidant capacities. The impact of NTP on specific bioactive compounds depends both on plasma properties and the food matrix. Induced changes are mainly associated with oxidative degradation and cleavage of double bonds in organic compounds. The effects reported to date are mainly time-dependent increases in the concentrations of polyphenols, vitamin C, or increases in antioxidant activity. Also, improvement in the extraction efficiency of polyphenols is observed. The review highlights future research needs regarding the complex mechanisms of interaction with plasma species. NTP is a novel technology that can both negatively and positively affect the functional components in food.
\end{abstract}

Keywords: antimicrobial peptides, antioxidant activity, ascorbic acid, bioactive compounds, cold plasma, polyphenols

\section{Introduction}

Fruits and vegetables $(\mathrm{F} \& \mathrm{~V})$ are known for their health benefits. However, given the complexity of the modern food supply chain, most foods are subjected to some degree of processing to preserve their freshness. Such intervention may modify the functional components of F\&V or their juices (Bevilacqua et al., 2017; Gironés-Vilaplana, Huertas, Moreno, Periago, \& García-Viguera, 2016). The term "functional components" refers to particular biomolecules found in foods which, apart from their basic nutritional properties, have the ability to protect human vital organs from diseases (Abuajah, Ogbonna, \& Osuji, 2015). Although functional components are not regarded as medicine, their importance in a "healthy" diet for disease prevention is now universally accepted. Functional components include nontoxic phytochemicals which are derived from plant-based foods like fruits, vegetables,

CRF3-2018-0094 Submitted 4/19/2018, Accepted 6/14/2018. Authors Muhammad, Liao, Liu, Chen, Ye, and Ding are with Dept. of Food Science and Nutrition, Zhejiang Key Laboratory for Agro-Food Processing, Zhejiang Univ., Hangzhou, Zhejiang, 310058, China. Author Muhammad is with Dept. of Agricultural and Environmental Engineering, Faculty of Engineering, Bayero Univ. Kano, Nigeria. Autho Cullen is with BioPlasma Research Group, Dublin Inst. of Technology, Dublin, Ire land. Author Cullen is with Dept. of Chemical and Environmental Engineering Univ. of Nottingham, Nottingham, NG7 2RD, United Kingdom. Author Xiang is with College of Food and Biological Engineering, Zhengzhou Univ. of Light Industry, Zhengzhou, 450002, P.R. China. Author Wang is with College of Food Science and Engineering, Qingdao Agricultural Univ., Chengyang, Qingdao, China. Direct inquiries to author Liu (E-mail: dhliu@zju.edu.cn; tding@zju.edu.cn). and whole grains (Craig, 1997; Idehen, Tang, \& Sang, 2016; Liu, 2007)

Bioactive compounds are not nutritious but are considered as antioxidants that work alongside fiber, minerals, and vitamins to boost human health (Gironés-Vilaplana et al., 2016; Kongkachuichai, Charoensiri, Yakoh, Kringkasemsee, \& Insung, 2015; Liu, 2013; Mann, 2011). Phytochemicals include phenolic compounds, carotenoids, sulfides, phytosterols, glucosinolates, lycopene, isoflavones, $\beta$-glucan, and lignans (Idehen et al., 2016; Liu, 2013; Mann, 2011; Noomhorm, Ahmad, \& Anal, 2014; Schreiner \& Huyskens-Keil, 2006). Approximately 900 phytochemicals have been identified in foods. A serving of F\&V may contain nearly 100 different phytochemicals (Srividya, Venkatesh, \& Vishnuvarthan, 2010). Bioactive compounds are also found in animals and include long-chain omega-3 polyunsaturated fatty acids, bioactive peptides, linolenic acid conjugates, and probiotic microorganisms. They are derived from animal products such as fish, milk, and fermented milk products (Abuajah et al., 2015). All the aforementioned bioactive components have been linked with dual-purpose effects of providing nourishment and lowering or preventing diseases, such cardiovascular disease, breast cancer, diabetes, and obesity (Idehen et al., 2016; Zhao et al., 2016). In view of their significance, there is a need to study how processing techniques may affect their functionality. Likewise, it is noteworthy that conventional thermal processing may have significant adverse effects on such food components. Sensitive food components such as volatiles, governing aroma, may be destroyed leading to lower-value products (Galanakis, 2017). Functional components 
in different food matrices are also found to be impaired due to their thermolabile characteristics (Howard, Jeffery, Wallig, \& Klein, 1997; Song \& Milner, 2001), and significant amounts of bioactive compounds in thermally preserved $F \& V$ are lost along with their freshness and succulent nature (Bahram-Parvar \& Lim, 2018; Bevilacqua et al., 2017; Gironés-Vilaplana et al., 2016). In a study on phenolic compound degradation due to heating, a model solution of flavonols, rutin, and quercetin was found to be degraded after cooking, and their radical-scavenging activity was reduced. The new products formed from the quercetin degradation retained about 20\% scavenging activity (Buchner, Krumbein, Rohn, \& Kroh, 2006). Consequently, the demand for whole and fresh-cut ready-to-eat F\&V by consumers over the years has led to a surge in demand for nonthermal treatments of high-value food products (Coutinho et al., 2018; Filho et al., 2016). Nonthermal technologies are typically found to be superior treatment techniques due to their reduced quality deterioration and beneficial influence on functional activity enhancement. Foods subjected to innovative technologies like ultrasound, gamma irradiation, high-hydrostatic-pressure processing, pulsed electric field, ultraviolet irradiation (UV-C), ozone, plasma-activated water (PAW), and cold atmospheric plasma have been reported to improve the retention of key nutrients, quality, and functional properties (Aguiló-Aguayo, Gangopadhyay, Lyng, Brunton, \& Rai, 2017; Barba et al., 2017; Cano, Hernandez, \& Ancos, 1997; Galanakis, 2017; Ma et al., 2015; Thirumdas, Sarangapani, \& Annapure, 2014; Thirumdas, Trimukhe, Deshmukh, \& Annapure, 2016; Zhang et al., 2017; Zhang, Chen, Li, Li, \& Zhang, 2015). The antimicrobial effects of these technologies has since been established, and many comprehensive review and research articles have been published (Aguiló-Aguayo, Charles, Renard, Page, \& Carlin, 2013; Fernández, Noriega, \& Thompson, 2013; Liao, Liu, Xiang, Ahn, Chen, Ye, \& Ding, 2017a; Liao, Muhammad, Chen, $\mathrm{Hu}$, Ye, Liu, \& Ding (2018) Niemira, 2012; Pignata, Angelo, Fea, \& Gilli, 2017; Scholtz, Pazlarova, Souskova, Khun, \& Julak, 2015; Weltmann et al., 2008; Ziuzina, Patil, Cullen, Keener, \& Bourke, 2014). Apart from their antimicrobial effects, processing with some of the aforementioned technologies has the capability of inducing functional modification of higher-molecular-weight biomolecules like starch and protein. This may come with undesired effects from the formation of short-chain aldehydes with toxic metabolites (Dong, Gao, Xu, \& Chen, 2017; Liao et al., 2018; Liao et al., 2017a; Muhammad, Xiang, Liao, Liu, \& Ding, 2018; Pankaj, Bueno-ferrer, Misra, Bourke, \& Cullen, 2014; Sarangapani et al., 2016; Thirumdas et al., 2016; Zhu, 2017). In general, nonthermal plasma technology (NTPT) is an innovative technology with a diverse range of applications across different industries, such as improving the adhesion, functional, and surface energy properties of polymers and electronics, treatments of textile materials and waste water, wound healing, and sterilization of medical equipment (Harry, 2010; Joubert et al., 2013; Lotfy, 2017; Muhammad et al., 2018; Pankaj \& Keener, 2018; Roth, 1995; Takai, Kitano, Kuwabara, \& Shiraki, 2012; Xinpei Lu et al., 2008; Yildirim et al., 2008). In food applications, the antimicrobial effect of NTP has been demonstrated for many products. A rapidly expanding body of literature can be found regarding the potent plasma efficacy of plasma-reactive species (RS), such as reactive oxygen species (ROS) and reactive nitrogen species (RNS) and their interactions with microorganisms on different food matrices (Ekezie, Sun, \& Cheng, 2017; Fernández, Shearer, Wilson, \& Thompson, 2012; Fridman et al., 2007; Kostov et al., 2010; Laroussi, Mendis, \& Rosenberg, 2003; Liao, et al., 2017a;
Liao, Xiang, Liu, Chen, Ye, \& Ding, 2017b; Mir, Shah, \& Mir, 2016; Misra, Keener, Bourke, Mosnier, \& Cullen, 2014; Misra, Tiwari, Raghavarao, \& Cullen, 2011; Niemira, 2012; Pankaj, Misra, \& Cullen, 2013; Smet et al., 2017; Surowsky, Schlüter, \& Knorr, 2014; Ziuzina et al., 2014). However, the effects of NTP treatment on lower-molecular-weight bioactive compounds have been studied to a lesser degree. Consequently, this review presents an overview of recent studies on the application of NTP on functional components, vitamins, and their antioxidant potentials. The review also discusses the possible plasma mechanisms of degradation or enhancement of functional components.

\section{Nonthermal Plasma (NTP) Generation}

Plasma exists as the fourth state of matter after solid, liquid, and gas. There are two key classifications of plasma, thermal (equilibrium) and nonthermal (nonequilibrium) plasma. A thermal plasma is generated when a gas is heated at a high-temperature range of about $20000 \mathrm{~K}$ to achieve the ionization of the gas. At this condition, all the ions, electrons, and chemical species are in thermodynamic equilibrium (Harry, 2010; Misra, Schlüter, \& Cullen, 2016). In the NTP, the applied energy leads to an elastic collision of the gas particles, atoms, and electrons. This results in the transfer of some kinetic energy to other particles in such a way that the cooling of the uncharged particles and neutral ions is more rapid than the energy transfer from the electrons. At this point, the electrons are at a higher temperature of between 1 and 10 $\mathrm{eV}$, while the neutrons, ions, and radicals remain close to room temperature. This allows the gas bulk to remain at a low temperature, hence the plasma is referred as NTP (Fridman, 2008; Harry, 2010; Misra et al., 2016; Scholtz et al., 2015). Such conditions enable the treatment of thermolabile food materials. The NTP can be generated through ionization of gases, such as $\mathrm{N}_{2}, \mathrm{O}_{2}$, or noble gases $(\mathrm{He}, \mathrm{Ar}$, or $\mathrm{Ne}$ ) or combinations thereof that could either be at a reduced or atmospheric pressure (Ekezie et al., 2017; Niemira, 2012; Pinela \& Ferreira, 2017; Scholtz et al., 2015). NTP can be generated by any type of energy, such as electrical, photoionization, optical (UV light), heat radiation, radio frequency, and microwave energy. The most prominent are electrical or electromagnetic energy (Fridman, 2008; Liao et al., 2017a; Pankaj \& Keener, 2017). The key NTP species for biological treatments are often found to be ROS, such as superoxide anion $\left(\mathrm{O}_{2}{ }^{-}\right)$, atomic oxygen $(\mathrm{O})$, singlet oxygen $\left({ }^{1} \mathrm{O}_{2}\right)$, hydroxyl radical $(\mathrm{OH} \bullet)$, and ozone $\left(\mathrm{O}_{3}\right)$; RNS, such as excited nitrogen $\mathrm{N}_{2}$, atomic nitrogen $\mathrm{N}$, nitric oxide NO•; and also UV photons, positive and negative ions, and free electrons (Laroussi \& Leipold, 2004; Liao et al., 2018; Ni, Lynch, Modic, Whalley, \& Walsh, 2016; Schlüter \& Fröhling, 2014; Scholtz et al., 2015).

In recent years, there has been an increasing number of studies in the literature on the application of NTP in foods, with different devices employed for generating the plasma discharges at atmospheric pressure with both direct or indirect food exposure. The schematic representation in Figure 1 shows a direct plasma exposure on target food materials with devices like dielectric barrier discharge (DBD) plasma, corona discharge plasma, gliding arc discharge plasma, and microwave cold plasma. Other plasma discharge devices are dielectric barrier grating discharge plasma, radio frequency plasma, nanosecond pulse plasma, and multijet atmospheric plasma discharges shown in Figure 2 (Chiang et al., 2010; Cullen et al., 2017; Gallagher Jr et al., 2007; Joubert et al., 2013; Kim, Oh, Won, Lee, \& Min, 2017; Korachi, Gurol, \& Aslan, 2010; Liao et al., 2017b; Moreau et al., 2007; Pankaj et al., 2015; Park et al., 2015). A comprehensive description of 
Table 1-Effect of NTP treatment on the functional components of food.

\begin{tabular}{|c|c|c|c|c|c|c|}
\hline NTP type & Treatment conditions & $\begin{array}{l}\text { Bioactive } \\
\text { compounds }\end{array}$ & Food commodity & Matrix & Observation & References \\
\hline $\begin{array}{l}\text { Atmospheric } \\
\text { pressure plasma } \\
\text { jet }\end{array}$ & $\begin{array}{l}0.20,40,80, \text { and } 120 \mathrm{~s} ; \\
35 \mathrm{~W} ; 27.12 \mathrm{MHz} ;\end{array}$ & Flavonoids & Lamb lettuce & Lettuce leaf & $\begin{array}{l}\text { - Reduction in phenolic } \\
\text { acids levels. } \\
\text { - Decrease in caffeic acids. } \\
\text { - Increase in diosmetin. }\end{array}$ & $\begin{array}{l}\text { Grzegorzewski } \\
\text { et al. (2011b) }\end{array}$ \\
\hline $\begin{array}{l}\text { Cold atmospheric } \\
\text { gas phase } \\
\text { plasma }\end{array}$ & $\begin{array}{l}3 \text { and } 5 \text { min; } 4 \mathrm{~W} ; 25 \mathrm{kHz} \text {; } \\
\text { argon gas; } 3,5 \text {, and } \\
7 \mathrm{~cm}^{3} \text { sample volume. }\end{array}$ & $\begin{array}{l}\text { Hydroxycinnamic } \\
\text { acids, flavonols, } \\
\text { polyphenols, }\end{array}$ & Chokeberry juice & Juice & $\begin{array}{l}\text { - Increase in } \\
\text { - } \text { Indroxycinnamic acids. } \\
\text { - Increase in flavonols } \\
\text { - } \text { Reduction in extraction } \\
\text { time of anthocyanins. } \\
\text { - Increase in } \\
\text { concentration of } \\
\text { neochlorogenic acid. }\end{array}$ & $\begin{array}{l}\text { Kovačević } \\
\text { et al. }(2016 a)\end{array}$ \\
\hline $\begin{array}{l}\text { High-voltage } \\
\text { atmospheric } \\
\text { cold plasma }\end{array}$ & $\begin{array}{l}0,1,2,3 \text {, and } 4 \mathrm{~min} ; \\
80 \mathrm{kV} ; 46 \% \mathrm{RH} .\end{array}$ & $\begin{array}{l}\text { Phenols, } \\
\text { flavonoids, and } \\
\text { flavonols }\end{array}$ & White grape & Juice & $\begin{array}{l}\text { - A decrease in total } \\
\text { phenolics. } \\
\text { - A decline in flavonoids. } \\
\text { - Increase in total } \\
\text { flavonols. }\end{array}$ & $\begin{array}{l}\text { Pankaj et al. } \\
(2017)\end{array}$ \\
\hline $\begin{array}{l}\text { Cold } \\
\text { Atmospheric } \\
\text { pressure plasma }\end{array}$ & $\begin{array}{l}0,2.5,5 \text { and } 10 \mathrm{~min} ; \\
3 \mathrm{kHz} ; 9 \mathrm{kV} \text {; Air; }\end{array}$ & $\begin{array}{l}\text { Flavonoid } \\
\text { glycosides }\end{array}$ & Pea & $\begin{array}{l}\text { Seed and } \\
15-d \text { old } \\
\text { Pea } \\
\text { seedlings }\end{array}$ & $\begin{array}{l}\text { - A reduced concentration } \\
\text { of quercetin glycosides. } \\
\text { - Kaempferol glycosides } \\
\text { concentrations were } \\
\text { decreased. }\end{array}$ & $\begin{array}{l}\text { Bußler et al. } \\
(2015)\end{array}$ \\
\hline $\begin{array}{l}\text { Cold atmospheric } \\
\text { gas phase } \\
\text { plasma }\end{array}$ & $\begin{array}{l}3,5,7 \mathrm{~min} ; 4 \text { w power; } \\
25 \mathrm{kHz} ; 0.75,1 \\
1.25 \mathrm{dm}^{3} \text { gas flow rate }\end{array}$ & Anthocyanin & pomegranate & Juice & $\begin{array}{l}\text { - Increase in anthocyanin } \\
\text { content. } \\
\text { - Positive impact on } \\
\text { anthocyanin stability. }\end{array}$ & $\begin{array}{l}\text { Kovačević } \\
\text { et al. (2016b) }\end{array}$ \\
\hline $\begin{array}{l}\text { Radio-frequency } \\
\text { (RF)-glow } \\
\text { low-pressure } \\
\text { oxygen plasma }\end{array}$ & $\begin{array}{l}20-300 \text { s: } 75 \mathrm{~W} \text {, and } \\
150 \mathrm{~W}^{\circ} \mathrm{O}_{2} \text { gas at } \\
0.5 \mathrm{mbar}^{2}\end{array}$ & $\begin{array}{l}\text { Phenolic acids, } \\
\text { Flavonoids }\end{array}$ & Lamb's lettuce & Leaf & $\begin{array}{l}\text { - Increase in } \\
\text { protocatechuic acid. } \\
\text { - Increase in luteolin and } \\
\text { diosmetin. }\end{array}$ & $\begin{array}{l}\text { Grzegorzewski } \\
\text { et al. (2010a) }\end{array}$ \\
\hline $\begin{array}{l}\text { Atmospheric } \\
\text { RF-plasma jet }\end{array}$ & $\begin{array}{l}60 \mathrm{~s} ; 20 \text { and } 40 \mathrm{w} ; \\
20-600 \mathrm{kHz}\end{array}$ & $\begin{array}{l}\text { Total phenolics } \\
\text { content }\end{array}$ & Dragon fruit & $\begin{array}{l}\text { Dragon fruit } \\
\text { slice }\end{array}$ & $\begin{array}{l}\text { - Reduction in total } \\
\text { phenolic contents. }\end{array}$ & $\begin{array}{l}\text { Matan et al. } \\
(2015)\end{array}$ \\
\hline $\begin{array}{l}\text { Atmospheric } \\
\text { double barrier } \\
\text { discharge } \\
\text { plasma }\end{array}$ & $\begin{array}{l}\text { Air, } 60 \% \text { RH; } 15 \mathrm{kV} ; \\
10+10 \text { and } 20+20 \mathrm{~min} .\end{array}$ & $\begin{array}{l}\text { Total phenolics } \\
\text { content, } \\
\text { Carotenoids }\end{array}$ & Kiwifruit & $\begin{array}{l}\text { Fresh-cut } \\
\text { Kiwifruit }\end{array}$ & $\begin{array}{l}\text { - No significant change in } \\
\text { total phenolic contents. } \\
\text { - A decrease in total } \\
\text { carotenoids. }\end{array}$ & $\begin{array}{l}\text { Ramazzina } \\
\text { et al. (2015) }\end{array}$ \\
\hline Cold plasma & $\begin{array}{l}\mathrm{N}_{2} \text { gas; } 10,30 \text {, and } \\
50 \mathrm{~mL} / \mathrm{min} \text { flow rate; } 5 \text {, } \\
10 \text { and } 15 \text { min; } 80 \mathrm{kHz} ; \\
30 \mathrm{kPa} \text { vacuum } \\
\text { conditions. }\end{array}$ & TPC and TFC & $\begin{array}{l}\text { Cashew apple } \\
\text { juice }\end{array}$ & Juice & $\begin{array}{l}\text { - Increase in TPC and TFC } \\
\text { at a higher gas flow rate. } \\
\text { - Overexposure led to } \\
\text { degradation of TPC and } \\
\text { TFC. }\end{array}$ & $\begin{array}{l}\text { Rodríguez } \\
\text { et al. (2017) }\end{array}$ \\
\hline $\begin{array}{l}\text { Cold atmospheric } \\
\text { gas phase } \\
\text { plasma }\end{array}$ & $\begin{array}{l}\text { Argon gas; } 3,5 \text {, and } \\
7 \mathrm{~min} ; 25 \mathrm{kHz} ; 4 \mathrm{~W} ; 3,4, \\
\text { and } 5 \mathrm{~cm}^{3} \text { sample } \\
\text { volume; } 0.75,1 \text {, } \\
1.25 \mathrm{dm}^{3} / \mathrm{min} \text { flow rate. }\end{array}$ & $\begin{array}{l}\text { Phenolic } \\
\text { compounds }\end{array}$ & $\begin{array}{l}\text { Pomegranate } \\
\text { juice }\end{array}$ & Juice & $\begin{array}{l}\text { - Increase in } \\
\text { concentrations of ellagic } \\
\text { acid, chlorogenic acid, } \\
\text { ferulic acid, catechin and } \\
\text { punicalagin } 1 \text {. } \\
\text { - Reduction in contents of } \\
\text { protocatechuic acid, } \\
\text { caffeic acid and } \\
\text { punicalagin } 2 \text {. }\end{array}$ & $\begin{array}{l}\text { Herceg et al. } \\
(2016)\end{array}$ \\
\hline $\begin{array}{l}\text { Atmospheric cold } \\
\text { plasma }\end{array}$ & $\begin{array}{l}\text { Air; 15, 30, 45, and } 60 \mathrm{~s} ; \\
70 \mathrm{kV} ; 50 \mathrm{~Hz} ; 22 \mathrm{~mm} \\
\text { electrode distance; }\end{array}$ & $\mathrm{TPC}$ & $\begin{array}{l}\text { Prebiotic orange } \\
\text { juice }\end{array}$ & Juice & $\begin{array}{l}\text { - Reduction in TPC } \\
\text { irrespective of direct or } \\
\text { indirect exposure. }\end{array}$ & $\begin{array}{l}\text { Almeida et al. } \\
(2015)\end{array}$ \\
\hline $\begin{array}{l}\text { Atmospheric cold } \\
\text { plasma }\end{array}$ & $\begin{array}{l}30,60,90 \text {, and } 120 \mathrm{~s} ; \\
650 \mathrm{~W} ; 3000 \mathrm{~L} / \mathrm{h} \text { gas } \\
\text { flow rate; } 25 \mathrm{kHz} \text {. }\end{array}$ & TPC & $\begin{array}{l}\text { Sour cherry } \\
\text { nectar, apple, } \\
\text { orange, and } \\
\text { tomato juices }\end{array}$ & Juice & $\begin{array}{l}\text { - An overall increase in } \\
\text { TPC in all treated juices } \\
\text { after } 120 \mathrm{~s} \text {. }\end{array}$ & $\begin{array}{l}\text { Dasan and } \\
\text { Boyaci } \\
(2018)\end{array}$ \\
\hline $\begin{array}{l}\text { Gas phase } \\
\text { plasma }\end{array}$ & $\begin{array}{l}\text { 3, 4, and } 5 \text { min; Ar gas; } \\
4 \mathrm{~W} ; 2.5 \mathrm{kV} ; 25 \mathrm{kHz} ; 2,3 \\
\text { and } 4 \mathrm{~mL} \text { sample; } 0.75 \\
1,1.25 \mathrm{~L} / \mathrm{min} \text { gas flow } \\
\text { rate. }\end{array}$ & TPC and TAC & $\begin{array}{l}\text { Sour cherry } \\
\text { Marasca juice }\end{array}$ & Juice & $\begin{array}{l}\text { - Higher TPC was } \\
\text { recorded at shorter } \\
\text { treatment time. } \\
\text { - } \text { Lower TAC observed at } \\
\text { longer treatment time. }\end{array}$ & $\begin{array}{l}\text { Garofulić et al. } \\
\text { (2015) }\end{array}$ \\
\hline $\begin{array}{l}\text { Atmospheric cold } \\
\text { plasma }\end{array}$ & $\begin{array}{l}\text { Air as gas; 0, 2, and } 5 \text { min; } \\
60 \text { and } 80 \mathrm{kV} ; 50 \mathrm{~Hz} \text {. }\end{array}$ & $\begin{array}{l}\text { TPC, TFC, and } \\
\text { anthocyanin. }\end{array}$ & Blueberry & Fruit & $\begin{array}{l}\text { - A significant increase in } \\
\text { TPC and TFC after } 1 \text { min } \\
\text { plasma exposure. } \\
\text { - Significant reduction in } \\
\text { anthocyanin with } \\
\text { extended treatment } \\
\text { time. }\end{array}$ & $\begin{array}{l}\text { Sarangapani } \\
\text { et al. (2017) }\end{array}$ \\
\hline $\begin{array}{l}\text { Atmospheric cold } \\
\text { plasma }\end{array}$ & $\begin{array}{l}\text { Air; } 0,15,30,45,60,90, \\
\text { and } 120 \mathrm{~s} ; 549 \mathrm{~W} ; \\
47 \mathrm{kHz} ; 7.5 \mathrm{~cm} \text { electrode } \\
\text { distance; } 113.27 \mathrm{~L} / \mathrm{min} \\
\text { flow rate. }\end{array}$ & Anthocyanin & Blueberries & Fruit & $\begin{array}{l}\text { - A significant decrease in } \\
\text { TAC after } 90 \mathrm{~s} \text {. }\end{array}$ & $\begin{array}{l}\text { Lacombe et al. } \\
(2015)\end{array}$ \\
\hline
\end{tabular}


Table 1-Continued.

\begin{tabular}{|c|c|c|c|c|c|c|}
\hline NTP type & Treatment conditions & $\begin{array}{l}\text { Bioactive } \\
\text { compounds }\end{array}$ & Food commodity & Matrix & Observation & References \\
\hline $\begin{array}{l}\text { Microwave- } \\
\text { powered cold } \\
\text { plasma }\end{array}$ & $\begin{array}{l}\mathrm{N}_{2} \text { gas; } 2,5 \text {, and } 10 \text { min; } \\
900 \mathrm{~W} ; 0.25 \mathrm{Wm}^{-2} \\
\text { wave; } 20 \mathrm{~L} / \mathrm{min} \text { gas flow } \\
\text { rate }\end{array}$ & TPC & $\begin{array}{l}\text { Mandarin flesh } \\
\text { and mandarin } \\
\text { peel }\end{array}$ & Fruit & $\begin{array}{l}\text { - No significant increase } \\
\text { in TPC within the flesh. } \\
\text { - A significant increase in } \\
\text { TPC in the peel. }\end{array}$ & $\begin{array}{l}\text { Yeon et al. } \\
(2017)\end{array}$ \\
\hline Cold plasma & $\begin{array}{l}\mathrm{Ar} ; 1 \mathrm{~L} / \min ; 0,3,5,7,9 \\
10, \text { and } 11 ; 15 \mathrm{kV} ; \\
12 \mathrm{kHz} \text {. }\end{array}$ & TPC & Walnut & Nut & $\begin{array}{l}\text { - No effect on TPC on } \\
\text { fresh and dried walnut. }\end{array}$ & $\begin{array}{l}\text { Amini and } \\
\text { Ghoranneviss } \\
\text { (2016) }\end{array}$ \\
\hline $\begin{array}{l}\text { Microwave- } \\
\text { powered cold } \\
\text { plasma }\end{array}$ & $\begin{array}{l}\text { He gas; } 1 \mathrm{~L} / \mathrm{min} ; 10,14 \\
25,36, \text { and } 40 \text { min; } 400 \text {, } \\
474,650,826 \text {, and } \\
900 \mathrm{~W} ; 0.7 \mathrm{kPa} \text {. }\end{array}$ & Quercetin content & Onion powder & Powder & $\begin{array}{l}\text { - No significant alteration } \\
\text { in quercetin content. }\end{array}$ & $\begin{array}{l}\text { Kim et al. } \\
(2017)\end{array}$ \\
\hline $\begin{array}{l}\text { Dielectric barrier } \\
\text { discharge } \\
\text { atmospheric } \\
\text { cold plasma }\end{array}$ & $\begin{array}{l}\text { Air; } 30,40, \text { and } 50 \mathrm{~W} ; 0,5, \\
10,15,20,30, \text { and } 40 \mathrm{~s} ; \\
2 \mathrm{~mm} \text { electrode distance. }\end{array}$ & TPC & Apple juice & Juice & $\begin{array}{l}\text { - A decline in TPC with } \\
\text { increase and treatment } \\
\text { time and power. }\end{array}$ & $\begin{array}{l}\text { Liao et al. } \\
\text { (2018) }\end{array}$ \\
\hline
\end{tabular}

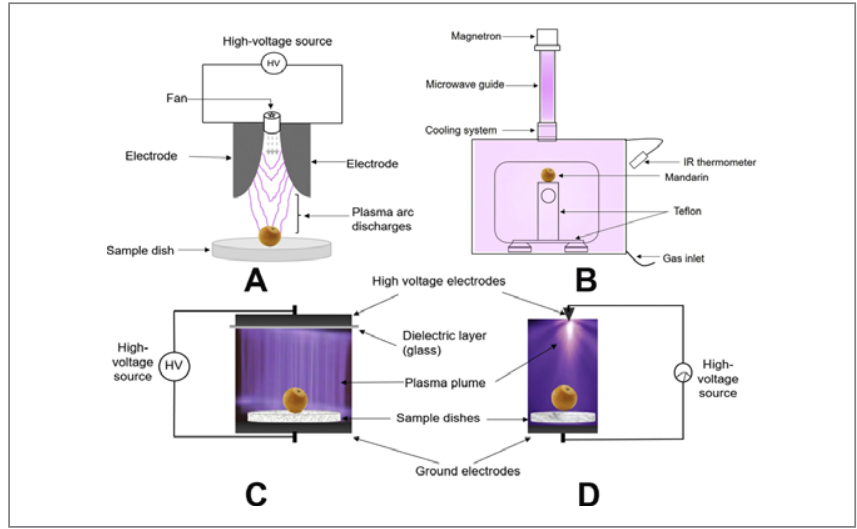

Figure 1-NTP discharge devices during direct exposure on food materials, (A) gliding arc discharge equipment, (B) microwave cold plasma generator (Yeon et al., 2017), (C) DBD plasma generator, and (D) corona discharge generator.

these devices is extensively discussed elsewhere ( $\mathrm{Lu}$, Laroussi, \& Puech, 2012; Misra et al., 2016; Muhammad et al., 2018; Schlüter \& Fröhling, 2014; Scholtz et al., 2015; Yildirim et al., 2008). Given the scale and generally low-value-added nature of food processing, the choice of gas is very important. Examination of the rapidly expanding literature shows a clear trend toward the use of atmospheric air as the operational gas of choice (Pignata et al., 2017), offering a cheap processing aid for food applications (Sarangapani, Patange, Bourke, Keener, \& Cullen, 2018).

\section{Mechanism of NTP Interaction with Functional Food Components}

Despite the number of research articles on the application of NTP in food, uncertainty exists between the mechanism of interaction of bioactive compounds and plasma RS. Unraveling the mechanisms involved is particularly challenging given the highly dynamic nature of plasma species. This relationship is likely to depend on several control conditions, such as the process gas, plasma source, input power, duration of exposure, and the distance between the discharge and the target. Elucidation of the mechanism is important for future approval of plasma as a food processing aid. The impact of NTPT on the functionality and stability of phenolic compounds is a structure-dependent phenomenon which may be explained by the synergistic effects of the various active plasma RS. A strong surface oxidation effect was proposed to have led to the addition of new carbonyl and carboxylic groups followed by heightened oxygen formation (Grzegorzewski, Michaela, Rohn, Kroh, \& Schlueter, 2011b; Grzegorzewski, Rohn, Kroh, Geyer, \& Schlüter, 2010b). Further addition of functional groups such as hydroxyl groups in the aromatic rings of phenolic compounds was documented by Aadil, Zeng, Han, and Sun (2013).

Comparably, the degradation of thermally treated model solutions of flavonoids (rutin and quercetin) is reported to be due to the presence of molecular oxygen $\left(\mathrm{O}_{2}\right)$ and $\mathrm{ROS}$ such as $\mathrm{O}_{2}{ }^{-}$, $\mathrm{OH} \bullet$. The final compounds formed were due to the shifting of some of the hydrogen atoms in the B-ring. Although the scavenging potentials of these compounds were reduced, they retained about 20\% of their scavenging activity (Buchner et al., 2006; Patras, Brunton, O'Donnell, \& Tiwari, 2010). Likewise, Makris and Rossiter (2002) have linked the degradation of phenolic compounds by plasma to that of a heat-induced oxidative cleavage path. However, Grzegorzewski and group hypothesized that the plasmainduced phenolics degradation was neither caused by photodesorption nor thermal desorption processes, it was rather induced by the combined effects of numerous plasma RS (Grzegorzewski et al., 2009; Grzegorzewski, Ehlbeck, Schlüter, Kroh, \& Rohn, 2011b). In quercetin, for example (Figure 3A), an initial hydrogen removal from the hydroxyl group in the $\mathrm{C}-4$ ' position is due to the potent influence of atomic oxygen $(\mathrm{O})$ and $\mathrm{OH} \bullet$. A subsequent slower degradation is due to hydrogen inhibition via substitution with $\beta$-O-linked D-glucose (quercetin-4'-O- monoglucoside) or steric interference in an adjacent position to quercetin-3,4'-Odiglucoside at C-3' (Grzegorzewski et al., 2010b).

In a similar study, Makris and Rossiter (2002) proposed a hydroxyl free radical oxidative degradation of flavonols (quercetin and morin) that formed low-molecular-weight phenolic compounds (Makris \& Rossiter, 2002). It was claimed that both compounds have similar degradation pathways that depend on B-ring and 3hydroxyl group substitutions (Grzegorzewski et al., 2009; Makris \& Rossiter, 2002). Grzegorzewski and group speculated that flavonoids degraded much faster than phenolic acids during NTP exposure. Their assertion was based on the radical-scavenging potential of polyphenols, which can scavenge the plasma-generated RS. This has allowed phenolic compounds to resist the degradation to a greater extent than flavonoids (Grzegorzewski et al., 2011b).

Another proposed mechanism of degradation for lowmolecular-weight organic compounds was ozone-induced 


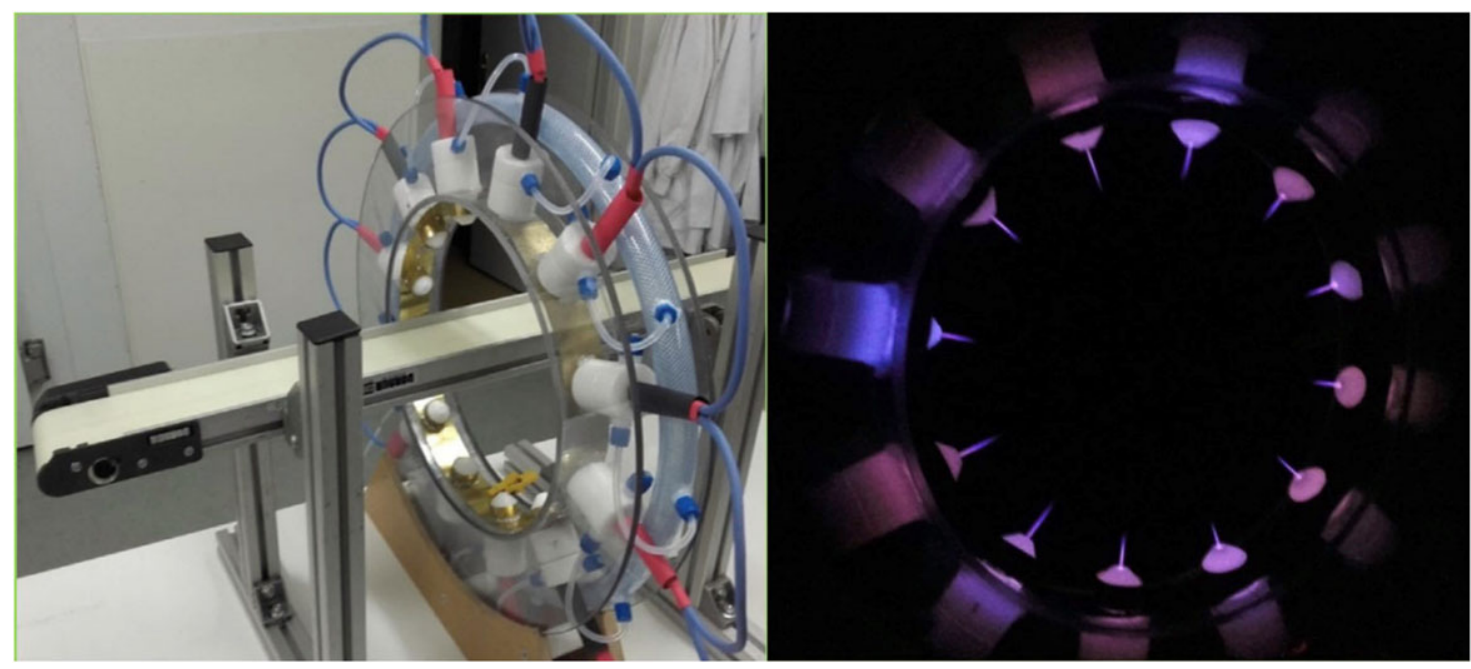

Figure 2-(A) 450-mm-diameter multijet plasma discharge designed for continuous treatment of food materials conveyed using a conveyor belt and a surrounding wall which helps in the retention of plasma RS (Cullen et al., 2017).

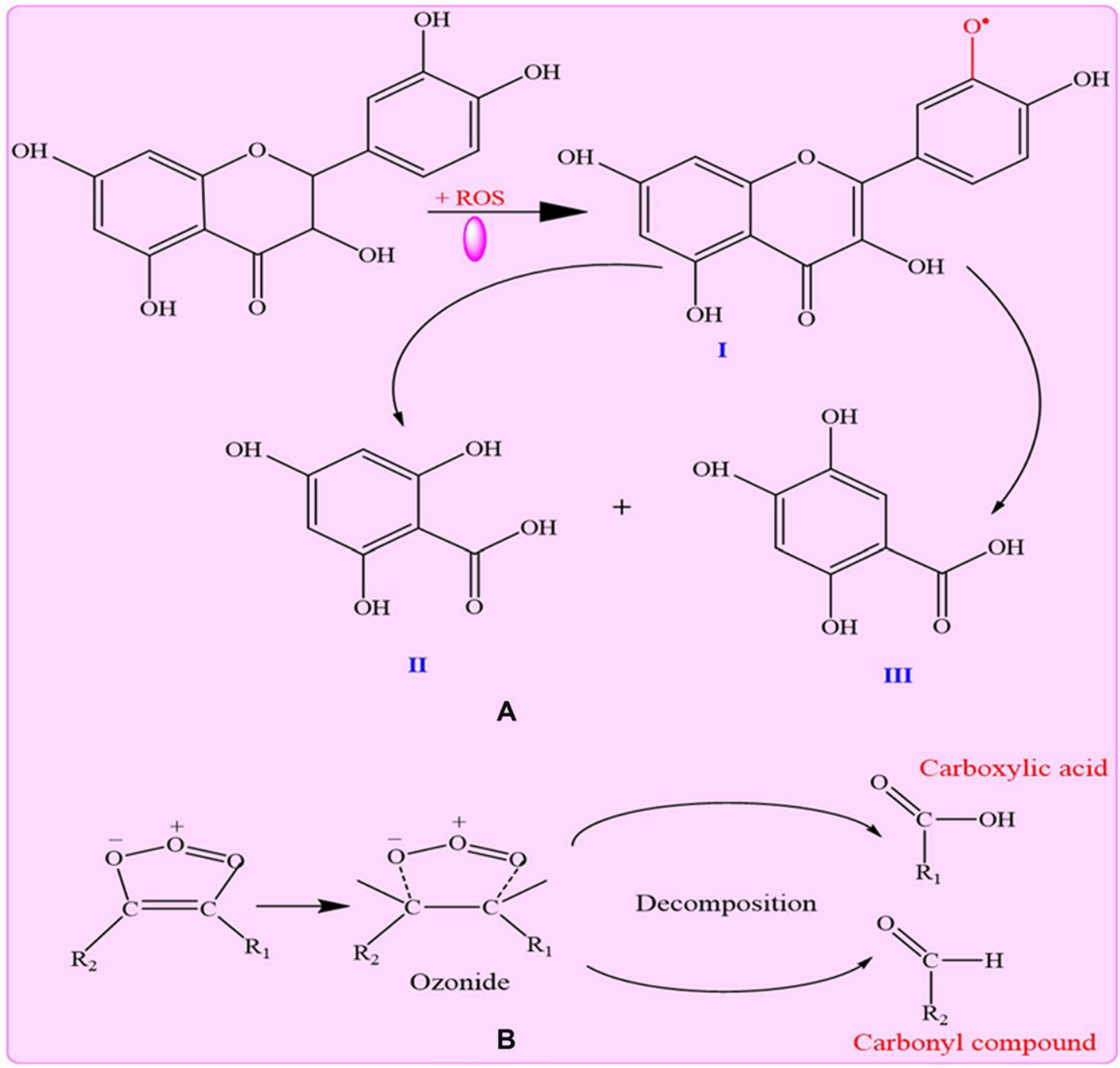

Figure 3-(A) Radical-induced oxidative degradation of quercetin leads to the formation of low-molecular-weight phenolic compounds II and III. The degradation path is similar to heat-induced oxidative cleavage (Grzegorzewski et al., 2010b). (B) Direct reaction of ozone and subsequent decomposition of ozonide to carboxylic acids and carbonyl compounds (Tiwari et al., 2009). 
Table 2-Effect of NTP treatment on antioxidant activity, antioxidant contents, and scavenging potential of functional food components.

\begin{tabular}{|c|c|c|c|c|c|c|}
\hline NTP type & Treatment conditions & $\begin{array}{l}\text { Scavenging } \\
\text { assay }\end{array}$ & $\begin{array}{c}\text { Food } \\
\text { commodity }\end{array}$ & Matrix & Observations & Reference \\
\hline $\begin{array}{l}\text { High-voltage } \\
\text { atmospheric cold } \\
\text { plasma }\end{array}$ & $\begin{array}{l}0,1,2,3 \text {, and } 4 \mathrm{~min} ; \\
80 \mathrm{kV} ; 46 \% \mathrm{RH} .\end{array}$ & DPPH & White Grape & Juice & $\begin{array}{l}\text { - A decrease in DPPH free } \\
\text { radical scavenging } \\
\text { activity. } \\
\text { - Reduction in antioxidant } \\
\text { capacity }\end{array}$ & $\begin{array}{l}\text { Pankaj et al. } \\
(2017)\end{array}$ \\
\hline $\begin{array}{l}\text { Atmospheric } \\
\text { double barrier } \\
\text { discharge plasma }\end{array}$ & $\begin{array}{l}\text { Air, } 60 \% \mathrm{RH} ; 15 \mathrm{kV} ; \\
10+10 \text { and } 20+20 \\
\text { min. }\end{array}$ & $\begin{array}{l}\text { ABTS, DPPH, } \\
\text { and FRAP }\end{array}$ & Kiwifruit & $\begin{array}{l}\text { Fresh-cut } \\
\text { Kiwifruit }\end{array}$ & $\begin{array}{l}\text { - No significant change in } \\
\text { antioxidant activity and } \\
\text { antioxidant contents in } \\
\text { all assays }\end{array}$ & $\begin{array}{l}\text { Ramazzina } \\
\text { et al. (2015) }\end{array}$ \\
\hline $\begin{array}{l}\text { Atmospheric cold } \\
\text { plasma }\end{array}$ & $\begin{array}{l}\text { Air, } 60 \% \text { RH; } 15 \text { and } \\
30 \text { min; } 70 \text { mm } \\
\text { discharge distance; } \\
15 \mathrm{kV} \text {. }\end{array}$ & $\begin{array}{l}\text { ABTS and } \\
\text { ORAC }\end{array}$ & Radicchio & $\begin{array}{l}\text { Radicchio } \\
\text { leaves }\end{array}$ & $\begin{array}{l}\text { - Slight decrease in } \\
\text { antioxidant activity in } \\
\text { both assays }\end{array}$ & $\begin{array}{l}\text { Pasquali et al. } \\
\text { (2016) }\end{array}$ \\
\hline Cold plasma & $\begin{array}{l}\mathrm{N}_{2} \text { gas; } 10,30 \text {, and } 50 \\
\text { mL/min flow rate; } 5 \text {, } \\
\text { 10, and } 15 \text { min; } 80 \\
\text { kHz; } 30 \text { kPa vacuum } \\
\text { conditions. }\end{array}$ & $\begin{array}{l}\text { FRAP, DPPH, } \\
\text { and ABTS }\end{array}$ & $\begin{array}{l}\text { Cashew apple } \\
\text { juice }\end{array}$ & Juice & $\begin{array}{l}\text { - An initial increase in } \\
\text { antioxidant activity in } \\
\text { the 1st } 5 \text { min at a low } \\
\text { flow rate. } \\
\text { - Reduction in antioxidant } \\
\text { activity at high flow } \\
\text { rates. }\end{array}$ & $\begin{array}{l}\text { Rodríguez } \\
\text { et al. (2017) }\end{array}$ \\
\hline $\begin{array}{l}\text { Atmospheric cold } \\
\text { plasma }\end{array}$ & $\begin{array}{l}\text { Air; } 15,30,45 \text {, and } 60 \\
\text { s; } 70 \mathrm{kV} ; 50 \mathrm{~Hz} ; 22 \\
\text { mm electrode } \\
\text { distance; }\end{array}$ & $\begin{array}{l}\text { DPPH, and } \\
\text { ABTS }\end{array}$ & $\begin{array}{l}\text { Prebiotic } \\
\text { orange juice }\end{array}$ & Juice & $\begin{array}{l}\text { - No significant change in } \\
\text { antioxidant capacity } \\
\text { using DPPH assay. } \\
\text { - A significant decrease in } \\
\text { antioxidant capacity } \\
\text { using ABTS assay. }\end{array}$ & $\begin{array}{l}\text { Almeida et al. } \\
(2015)\end{array}$ \\
\hline $\begin{array}{l}\text { Microwave- } \\
\text { powered cold } \\
\text { plasma }\end{array}$ & $\begin{array}{l}\mathrm{N}_{2} \text { gas; } 2,5, \text { and } 10 \\
\mathrm{~min} ; 900 \mathrm{~W} ; 0.25 \\
\mathrm{~W} / \mathrm{m}^{2} \text { wave; } 20 \\
\mathrm{~L} / \mathrm{min} \text { gas flow rate }\end{array}$ & $\mathrm{DPPH}$ & $\begin{array}{l}\text { Mandarin flesh } \\
\text { and } \\
\text { mandarin } \\
\text { peel }\end{array}$ & Fruit & $\begin{array}{l}\text { - No effect on scavenging } \\
\text { activity of the flesh. } \\
\text { - A significant increase in } \\
\text { activity for the peel. }\end{array}$ & $\begin{array}{l}\text { Yeon et al. } \\
(2017)\end{array}$ \\
\hline Cold plasma & $\begin{array}{l}\text { Ar; } 1 \mathrm{~L} / \min ; 0,3,5,7 \text {; } \\
9,10 \text {, and } 11 ; 15 \mathrm{kV} ; \\
12 \mathrm{kHz} \text {. }\end{array}$ & $\begin{array}{l}\text { FRAP and } \\
\text { DPPH }\end{array}$ & Walnut & Nut & $\begin{array}{l}\text { - No effect was observed } \\
\text { in all samples. }\end{array}$ & $\begin{array}{l}\text { Amini and } \\
\text { Ghoranneviss } \\
\text { (2016) }\end{array}$ \\
\hline $\begin{array}{l}\text { Microwave- } \\
\text { powered cold } \\
\text { plasma }\end{array}$ & $\begin{array}{l}\text { He gas; } 1 \mathrm{~L} / \mathrm{min} ; 10 \\
14,25,36 \text {, and } 40 \\
\text { min; 400,474,650, } \\
826 \text {, and } 900 \mathrm{~W} ; 0.7 \\
\mathrm{kPa} \text {. }\end{array}$ & DPPH & Onion powder & Powder & $\begin{array}{l}\text { - Increase in antioxidant } \\
\text { activity. }\end{array}$ & $\begin{array}{l}\text { Kim et al. } \\
(2017)\end{array}$ \\
\hline PAW & $\begin{array}{l}98 \% \text { Ar and } 2 \% \mathrm{O}_{2} ; 5 \\
\mathrm{~L} / \mathrm{min} \text { flow rate; } 10 \\
\mathrm{kHz} ; 10 \mathrm{~mm} \text { working } \\
\text { distance; PAW-5, } 10 \\
\text { and } 15 \mathrm{~min} .\end{array}$ & $\begin{array}{l}\text { UV/Vis } \\
\text { spectrometer }\end{array}$ & $\begin{array}{l}\text { Button } \\
\text { mushroom }\end{array}$ & Mushroom & - Increase in antioxidant. & $\begin{array}{r}\text { Xu et al. } \\
(2016)\end{array}$ \\
\hline Cold plasma & $\begin{array}{l}400 \text { and } 900 \mathrm{~W} ; 10 \\
\min ; \mathrm{N}_{2}, \mathrm{He}, \mathrm{N}_{2}+\mathrm{O}_{2}\end{array}$ & $\begin{array}{l}\text { DPPH and } \\
\text { ABTS }\end{array}$ & Lettuce & Vegetable & $\begin{array}{l}\text { - No significant effect on } \\
\text { the antioxidant } \\
\text { activities. }\end{array}$ & $\begin{array}{l}\text { Song et al. } \\
\text { (2015) }\end{array}$ \\
\hline $\begin{array}{l}\text { Microwave- } \\
\text { powered cold } \\
\text { plasma }\end{array}$ & $\begin{array}{l}\mathrm{N}_{2} ; 0,2,5,10, \text { and } 20 \\
\text { min; } 900 \mathrm{~W} ; 667 \mathrm{~Pa} ;\end{array}$ & ABTS & Radish sprout & Vegetable & $\begin{array}{l}\text { - Antioxidant activity was } \\
\text { not affected. }\end{array}$ & $\begin{array}{l}\text { Oh et al. } \\
(2017)\end{array}$ \\
\hline $\begin{array}{l}\text { Dielectric barrier } \\
\text { discharge } \\
\text { atmospheric cold } \\
\text { plasma }\end{array}$ & $\begin{array}{l}\text { Air; } 30,40, \text { and } 50 \mathrm{~W} ; \\
0,5,10,15,20,30, \\
\text { and } 40 \mathrm{~s} ; 2 \mathrm{~mm} \\
\text { electrode distance. }\end{array}$ & $\mathrm{DPPH}$ & Apple juice & Juice & $\begin{array}{l}\text { - A slight decrease in } \\
\text { antioxidant capacity. }\end{array}$ & $\begin{array}{l}\text { Liao et al. } \\
(2018)\end{array}$ \\
\hline
\end{tabular}

oxidative cleavage of the double bonds of organic compounds, which leads to the formation of unstable ozonide, which subsequently degrades. Such degradation follows either a direct reaction with $\mathrm{O}_{3}$ or indirect reaction with another $\mathrm{ROS}$ such as $\mathrm{O}_{2}{ }^{-}$or $\mathrm{OH} \cdot$. The indirect reaction leads to electrophilic and nucleophilic reactions with aromatic compounds which are replaced with an electron donor $\left(\mathrm{OH}^{-}\right)$with high electron affinity in the ortho and para positions. The direct reaction is explained by the Criegee mechanism, which involves subjecting ozone molecules to 1-3 dipolar cycloaddition with the double bonds. This results in the formation of ozonides (1,2,4-trioxolanes) from the unsaturated alkenes and then ozone with an aldehyde or ketone oxides, which have finite lifetimes. However, due to the instability of the ozonides, their oxidative degradation yields carbonyl compounds, and carboxylic acids or ketones, as shown in Figure 3(B) (Criegee, 1957; Tiwari, O’Donnell, \& Cullen, 2009).
Influence of NTP Treatment on Bioactive Compounds

Polyphenols are bioactive compounds that are mostly derived from plants. They consist of flavones, flavonols, flavan-3-ols, isoflavones, anthocyanidins, lignans, and so on. When consumed, they are metabolized in the body with synergistic effects of antioxidant, anti-inflammatory, and antimicrobial properties, resulting in a healthy body (Kristbergsson \& Ötles, 2016; Scalbert, Johnson, \& Saltmarsh, 2005; Siddiq, Ahmed, Lobo, \& Ozadali, 2012). NTP processing of $F \& V$ results in the alteration of composition and functionality of polyphenols. Table 1 highlights the effect of NTP treatment on various functional food components. For example, anthocyanins are phenolic flavonoids situated in the cell vacuole. NTP disruption of the cell membrane leads to the release of intracellular substances into the extracellular environment. Consequently, an improved mass transfer and faster penetration of solvents into the cell enhance the extraction of polyphenols 
Table 3-Effect of NTP treatment on vitamins (Vc).

\begin{tabular}{|c|c|c|c|c|c|c|}
\hline NTP type & Treatment conditions & Assay type & $\begin{array}{l}\text { Food } \\
\text { commodity }\end{array}$ & Matrix & Observations & Reference \\
\hline Cold plasma & $\begin{array}{l}\mathrm{N}_{2} \text { gas; } 10,30 \text {, and } 50 \\
\mathrm{~mL} / \mathrm{min} \text { flow rate; } 5,10, \\
\text { and } 15 \text { min; } 80 \mathrm{kHz} ; 30 \\
\mathrm{kPa} \text { vacuum conditions. }\end{array}$ & $\begin{array}{l}\text { UV/Vis } \\
\text { spectropho- } \\
\text { tometer }\end{array}$ & $\begin{array}{l}\text { Cashew apple } \\
\text { juice }\end{array}$ & Juice & $\begin{array}{l}\text { - An initial increase in Vc } \\
\text { content in the 1st } 5 \text { min } \\
\text { at a lower flow rate. } \\
\text { - Reduction in Vc content } \\
\text { at high treatment } \\
\text { conditions. }\end{array}$ & $\begin{array}{l}\text { Rodríguez } \\
\text { et al. (2017) }\end{array}$ \\
\hline $\begin{array}{l}\text { Atmospheric } \\
\text { cold plasma }\end{array}$ & $\begin{array}{l}15,30,45 \text {, and } 60 \mathrm{~s} ; 70 \\
\mathrm{kV} ; 50 \mathrm{~Hz} ; 22 \mathrm{~mm} \\
\text { electrode distance. }\end{array}$ & HPLC & $\begin{array}{l}\text { Prebiotic } \\
\text { Orange juice }\end{array}$ & Juice & $\begin{array}{l}\text { - Increase in ascorbic acid } \\
\text { content. }\end{array}$ & $\begin{array}{l}\text { Diva et al. } \\
(2017)\end{array}$ \\
\hline $\begin{array}{l}\text { Atmospheric } \\
\text { cold plasma }\end{array}$ & $\begin{array}{l}\text { Air as gas; 0, 2, and } 5 \mathrm{~min} ; \\
60 \text { and } 80 \mathrm{kV} ; 50 \mathrm{~Hz} \text {. }\end{array}$ & HPLC & Blueberry & Whole fruit & $\begin{array}{l}\text { - A significant increase in } \\
\text { ascorbic acid content at } \\
1 \text { min and } 80 \mathrm{kV} \text {. } \\
\text { - Significant decrease } \\
\text { after } 5 \text { min treatment } \\
\text { time and } 80 \mathrm{kV} \text {. }\end{array}$ & $\begin{array}{l}\text { Sarangapani } \\
\text { et al. (2017) }\end{array}$ \\
\hline $\begin{array}{l}\text { Microwave- } \\
\text { powered cold } \\
\text { plasma }\end{array}$ & $\begin{array}{l}\mathrm{N}_{2} \text { gas; } 2,5 \text {, and } 10 \mathrm{~min} ; \\
900 \mathrm{~W} ; 0.25 \mathrm{~W} / \mathrm{m}^{2} \\
\text { wave; } 20 \mathrm{~L} / \mathrm{min} \text { gas flow } \\
\text { rate }\end{array}$ & HPLC & $\begin{array}{l}\text { Mandarin flesh } \\
\text { and mandarin } \\
\text { peel }\end{array}$ & Whole fruit & $\begin{array}{l}\text { - Insignificant change in } \\
\text { ascorbic acid } \\
\text { concentration. }\end{array}$ & $\begin{array}{l}\text { Yeon et al. } \\
(2017)\end{array}$ \\
\hline PAW & $\begin{array}{l}98 \% \text { Ar and } 2 \% \mathrm{O}_{2} ; 5 \\
\text { L/min flow rate; } 10 \mathrm{kHz} \text {; } \\
10 \mathrm{~mm} \text { working distance; } \\
\text { PAW-5, 10, and } 15 \mathrm{~min} \text {. }\end{array}$ & $\begin{array}{l}\text { UV/Vis spec- } \\
\text { trometer }\end{array}$ & $\begin{array}{l}\text { Button } \\
\text { mushroom } \\
\text { Cucumber }\end{array}$ & Mushroom & $\begin{array}{l}\text { - Increase in Vc } \\
\text { concentration with } \\
\text { increase PAW. }\end{array}$ & $\begin{array}{l}\text { Xu et al. } \\
(2016)\end{array}$ \\
\hline $\begin{array}{l}\text { Atmospheric } \\
\text { cold plasma }\end{array}$ & $\begin{array}{l}\text { Air; flow rate } 5 \mathrm{slm} ; 30 \\
\mathrm{~mA} ; 500 \mathrm{~V} ; 0,30,60,90 \text {, } \\
150 \text {, and } 240 \mathrm{~s} .\end{array}$ & HPLC & $\begin{array}{l}\text { Carrot } \\
\text { Pear }\end{array}$ & Fruit Slices & $\begin{array}{l}\text { - } 3.6 \% \text { loss in Vc content } \\
\text { in cucumber slices. } \\
\text { - } 3.2 \% \text { loss in carrot } \\
\text { slices. } \\
\text { - } 2.8 \% \text { loss in pear slices. }\end{array}$ & $\begin{array}{l}\text { Wang et al. } \\
(2012)\end{array}$ \\
\hline Cold plasma & $\begin{array}{l}400 \text { and } 900 \mathrm{~W} ; 10 \mathrm{~min} ; \\
\mathrm{N}_{2}, \mathrm{He}, \mathrm{N}_{2}+\mathrm{O}_{2} ;\end{array}$ & HPLC & Lettuce & Vegetable & $\begin{array}{l}\text { - No significant effect was } \\
\text { observed. }\end{array}$ & $\begin{array}{l}\text { Song et al. } \\
(2015)\end{array}$ \\
\hline $\begin{array}{l}\text { Microwave- } \\
\text { powered cold } \\
\text { plasma }\end{array}$ & $\begin{array}{l}\mathrm{N}_{2} ; 0,2,5,10, \text { and } 20 \\
\text { min; } 900 \mathrm{~W} ; 667 \mathrm{~Pa} .\end{array}$ & HPLC & Radish sprout & Vegetable & $\begin{array}{l}\text { - MCP did not decrease } \\
\text { the ascorbic acid } \\
\text { concentration. }\end{array}$ & $\begin{array}{l}\text { Oh et al. } \\
(2017)\end{array}$ \\
\hline $\begin{array}{l}\text { High-voltage } \\
\text { atmospheric } \\
\text { cold plasma }\end{array}$ & $\begin{array}{l}90 \mathrm{kV} ; 60 \mathrm{~Hz} ; 30,60 \text {, and } \\
120 \mathrm{~s} ; 4.44 \mathrm{~cm} \text { electrode } \\
\text { gap. }\end{array}$ & HPLC & Orange juice & Juice & $\begin{array}{l}\text { - } 120 \text { s direct treatment } \\
\text { reduce Vc content by } \\
22 \% \text {. }\end{array}$ & $\begin{array}{l}\text { (Xu et al., } \\
2017)\end{array}$ \\
\hline
\end{tabular}

(Kobzev et al., 2013; Landbo \& Meyer, 2001). Grzegorzewski and coresearchers hypothesized that plasma ROS such as $\mathrm{OH} \bullet$ and $\mathrm{Ar}^{+}$have caused etching of the upper epidermis of lamb's lettuce which stimulated the release and degradation of flavonoids and other compounds from the central vacuoles of the guard cells (Grzegorzewski et al., 2011b). To study the degradation of NTP-treated chokeberry juice, Kovačević and coresearchers employed high-performance liquid chromatography equipped with UV/Vis-photo diode array detection (HPLC-DAD). Their results showed a $23 \%$ loss in anthocyanins due to their low stability in the juice coupled with the oxidative effect of the plasma RS. Also, increases in the concentration of neochlorogenic acid, quercetin-3-rutinoside, and quercetin-3-glucoside were observed. On extraction of the plasma-treated phytochemicals, a reduction in the extraction time of anthocyanins, and a decrease in the percentage volumes of neochlorogenic acid (5\%), caffeic acid (2\%), and quercetin-3-rutinoside (9\%) were recorded (Kovačević et al., 2016a). In another study on cold atmospheric gas plasma, the anthocyanin content of pomegranate juice was increased by about 21-35\%, thus affirming NTP's positive impact on anthocyanin stability (Kovačević et al., 2016b).

The contents of protocatechuic, chlorogenic, and caffeic acids in fresh lamb's lettuce were decreased by $16 \%, 29 \%$, and $35 \%$, respectively, after plasma exposure, while the diosmetin content was increased by $44 \%$, and the pure flavonoids (model solution) showed a strong time-dependent decrease after NTP treatment (Grzegorzewski et al., 2011b). Comparatively, negligible changes in the contents of chlorogenic and caffeic acids after UV-C expo- sure were reported by the same researchers. Conversely, protocatechuic acid, luteolin, and diosmetin were reported to be increased by $70 \%, 53 \%$, and $101 \%$, respectively, due to the damaging effects of UV-C on the epidermal and mesophyll cells (Grzegorzewski et al., 2011b). A divergent result of a 2 -fold increment in the protocatechuic acid and luteolin contents was observed after a 120-s treatment irrespective of the input power. The diosmetin content was also increased 2.5-fold in a similar manner (Grzegorzewski et al., 2010a).

Pankaj and coresearchers studied the effect of high-voltage cold atmospheric plasma on white grape juice, with an increase in the total flavonols content observed. It was further stated that the total phenolic and flavonoid contents (TPC and TFC) reduced drastically with increased treatment time (Pankaj, Wan, Colonna, \& Keener, 2017). In agreement with Pankaj et al. (2017), Herceg and coresearchers reported a $33.03 \%$ increase in TPC of plasmatreated pomegranate juice. Additionally, the ellagic acid content was 3 times higher in the plasma-treated juice than the untreated juice. This might be due to the plasma RS bombarding the cell membrane to induce hydrolysis and degradation of ellagitannins leading to increases in the ellagic acid increment (Herceg et al., 2016). The influence of ACP on orange, tomato, and apple juices, and on sour cherry nectar, was also reported. Following $120 \mathrm{~s}$ of treatment, the TPC in all the juices were increased by $9.52 \%, 14.81 \%, 14.43 \%$, and $14.47 \%$, respectively (Dasan \& Boyaci, 2018). From another research on sour cherry Marasca juice exposed to gas phase plasma, a time-dependent effect was observed. The highest concentration of total anthocyanins 
(TAC; $223.96 \mathrm{mg} / 100 \mathrm{~g}$ ) was recorded after $3 \mathrm{~min}$ of treatment. Likewise, a higher TPC of $163.36 \mathrm{mg} / 100 \mathrm{~g}$ was observed at the shortest exposure time of $3 \mathrm{~min}$, as against the samples treated for 5 min (Garofulić et al., 2015). These results point to the impact of NTP on phenolic degradation. Prolonged exposure of both anthocyanins and phenolic acids confirmed the reaction with plasma-induced ROS (Grzegorzewski et al., 2011b). Regardless of the applied voltage, a marked increase in TPC and TFC of blueberries after just $1 \mathrm{~min}$ of ACP treatment was reported. The research further showed a slight drop in both TPC and TFC as compared with untreated samples after the treatment was extended to $5 \mathrm{~min}$. Meanwhile, the anthocyanin content significantly dropped over extended periods of plasma treatment at higher input voltage (Sarangapani, O'Toole, Cullen, \& Bourke, 2017). The TPC in mandarin peel significantly rose after microwave-powered plasma treatment, while that in the mandarin flesh was not altered (Yeon, Jo, \& Min, 2017). An increase in TPC and polyphenolics could be described by the accumulation of phenolic compounds within the epidermal cells which are triggered by plasma RS such as UV that enhances their biosynthesis (Grzegorzewski et al., 2010a; Laroussi \& Leipold, 2004). Likewise, Matan and coresearchers suggested that NTP treatment alone caused a slight drop in TPC from $2.0 \pm 0.2 \mathrm{mg} \mathrm{100/g}$ to $1.9 \pm 0.1$ mg 100/g in dragon fruit. However, upon combining the dragon fruit with $5.0 \%$ green tea extract, a marked increase in TPC was noted (Matan, Puangjinda, Phothisuwan, \& Nisoa, 2015).

Meanwhile, a different result was reported by Almeida and coresearchers after NTP treatment of prebiotic orange juice. The result showed a marked reduction in the TPC from $2.52 \pm 0.20$ to $2.37 \pm 0.10 \mathrm{~g} / \mathrm{L}$ and $1.93 \pm 0.12 \mathrm{~g} / \mathrm{L}$ for direct and indirect exposure, respectively. In the indirect exposure, the TPC was significantly affected at $60 \mathrm{~s}$ of treatment. Likewise, after ozone treatment of the same juice, the TPC was slightly reduced to $2.33 \pm$ $0.07 \mathrm{~g} / \mathrm{L}$ (Almeida et al., 2015). It is also worth noting that $\mathrm{O}_{3}$ is generally present in significant amounts where the plasma inducer gas contains some level of oxygen (Mir et al., 2016; Misra et al., 2015; Surowsky et al., 2014). Apple juice treated with atmospheric cold plasma-DBD plasma showed a slight decrease in TPC at an input power of 30 and $40 \mathrm{~W}$. But after increasing the exposure time at $50 \mathrm{~W}$, the reduction in TPC was significant (Liao et al., 2018). Lacombe and co-researchers observed a significant decline in TAC for plasma-treated blueberries after $90 \mathrm{~s}$ of exposure (Lacombe et al., 2015), although many factors could have resulted in the change of anthocyanin stability. The processing temperature could accelerate the rate of degradation of anthocyanin via tempering with the enzymatic activity of $\beta$-glucosidase and polyphenol oxidase (Patras et al., 2010). In the flavonol glycoside profile of pea seeds, seedlings, and sprouts, a dose-dependent decline in the concentrations of flavonol was observed after NTP treatment. The concentrations of quercetin and kaempferol glycosides were reduced as the treatment time was extended. This might be due to their protective effects against oxidative stresses (Bußler et al., 2015).

Another research group reported non-significant effects of NTP treatment on TPC for some food products. Amini and Ghoranneviss (2016) recorded no effects for fresh and dried argon plasmatreated walnuts after an 11-min exposure. Meanwhile, in onion powder, the content of quercetin was not significantly affected following the microwave plasma treatment. Although onions have a high concentration of quercetin and quercetin glycosides, which degrade upon thermal processing (Aguiló-Aguayo et al., 2013), the plasma-treated quercetin content remained intact even after storage at $4{ }^{\circ} \mathrm{C}$ for $28 \mathrm{~d}$ (Kim et al., 2017). This was possibly due to the mild nature of the plasma treatment and the defense mechanism against oxidation. An onion of $10 \mathrm{~g}$ could provide about $4 \mathrm{mg}$ of quercetin, which is equivalent to the allowable daily intake of 8 to $10 \mathrm{mg} / \mathrm{d}$ of vitamin $\mathrm{E}$ for an adult (Bahram-Parvar \& Lim, 2018).

This section clearly highlights improvements, declines, and no notable effects of polyphenols after NTP treatment. These divergent results may be due to differences in the food matrices, plasma equipment configuration, and processing parameters, particularly the gas used. From the food processing perspective, the after-effect of NTP treatment on polyphenols warrants a comprehensive optimization of all process condition, in order to fully understand their interactions with target food matrices.

\section{Antimicrobial Peptides}

Antimicrobial peptides (AMPs) are low-molecular-weight biomolecules with a wide range of antimicrobial effects against fungi, bacteria, yeasts, virus, and cancer cells. These biomolecules are found naturally in living organisms as the first line of defense, with a varying number of amino acids (Bahar \& Ren, 2013; Bazaka, Jacob, Chrzanowski, \& Ostrikov, 2015; Villa \& Viñas, 2016; Zhang \& Gallo, 2016). However, bacteriocins are a subgroup of AMPs produced by bacteria, which can inhibit or kill closely related or nonrelated bacteria without posing any harm to the bacteria themselves (Yang, Lin, Sung, \& Fang, 2014). The majority of the bacteriocins are produced by lactic acid bacteria and are used as starters in food fermentation or as preservatives. These bioactive peptides can also be added as hurdle technologies in packaging systems for shelf life extension. For instance, nisin produced by Lactococcus lactis was approved by the US Food and Drug Administration (FDA) to be used in processed cheese in 1988 (Røssland, Langsrud, Granum, \& Sørhaug, 2005; Villa \& Viñas, 2016). The pathway in which these peptides lead to bacteria death is via inhibiting the protein synthesis and DNA replication pathways thereby subduing the cellular functions (Brogden, 2005). Most AMPs are positively charged with hydrophilic and hydrophobic groups. These enable the peptides to target bacterial cell membranes by binding to the lipid and phospholipid components, which cause decomposition of the lipid bilayer (Izadpanah \& Gallo, 2005; Shai, 2002; Lijuan Zhang, Rozek, \& Hancock, 2001).

\section{Advantages and Limitations}

Interestingly, bacteriocins do not harm the producing strain due to specific immune proteins. Likewise, AMPs are stable to heat, can extend food preservation duration, and treat malignant cancers and pathogenic diseases. These peptides could potentially replace antibiotics to treat multiple drug-resistant pathogens (Ghrairi, Chaftar, \& Hani, 2012; Lancaster, Wintermeyer, \& Rodnina, 2007; Van Heel, Montalban-Lopez, \& Kuipers, 2011; Yang et al., 2014). However, despite the aforementioned benefits, there are some impending issues to their application in general. AMPs are susceptible to proteases such as pepsin and trypsin (Cleveland, Montville, Nes, \& Chikindas, 2001), could potentially be toxic to humans (Pacor, Giangaspero, Bacac, Sava, \& Tossi, 2002), are costly to produce (Bommarius et al., 2010), are bacterial resistance to some AMPs (Bader et al., 2005), and lack of selectivity against specific strain (Eckert et al., 2006).

Based on these challenges, AMPs could possibly be modified by NTP to improve some of the functionalities. Arndt and coresearchers reported the activation of $\beta$-defensin during wounding 
after NTP exposure (Arndt et al., 2015). Given the potential of this avenue of research, more NTP food-related research ought to be conducted to determine the possible AMPs enhancements for immobilization on food packaging materials. This could be potential new research area in active food packaging.

\section{Influence of NTP Processing on the Antioxidant Activity, Antioxidant Contents, and Scavenging Potential of Functional Food Components}

The major antioxidant and scavenging compounds in F\&V are vitamin $\mathrm{C}$, vitamin $\mathrm{E}$, and phenolic compounds. These bioactive compounds have the capacity to scavenge free radicals responsible for many diseases caused by oxidative stress and thereby minimize their risk (Aadil et al., 2013; Bajpai, Mishra, \& Prakash, 2017). The antioxidant components in fruit and vegetable tissues are liable to degrade upon interaction with light, oxygen, or exposure to enzymes, such as polyphenol oxidase, ascorbate oxidase, cytochrome oxidase, and peroxidase, after wounding (Gil, Aguayo, \& Kader, 2006). One major obstacle in the antioxidant determination is identifying the assays suitable for a particular application, as the antioxidants can induce numerous reactions, such as hydrogen peroxide or hydroperoxide decompositions, radicalscavenging, repairing biological damage, and quenching of active pro-oxidants. In such situations, the choice of the antioxidant assay should be based on its predefined function being measured (Apak, Özyürek, Güçlü, \& Çapanollu, 2016; Niki \& Noguchi, 2000). The antioxidant assays commonly used include organic radical-scavenging ability (2,2-azino-bis-3-ethylbenzthiazoline-6sulfonic acid, ABTS, and 2,2-diphenyl-1-picrylhydrazyl, DPPH), electron transfer ability (Folin-Ciocalteu, FC), and metalreduction ability (ferric-reducing antioxidant power, FRAP) (Altemimi, Lakhssassi, Baharlouei, Watson, \& Lightfoot, 2017). Over the years, there has been confusion on what is being determined in antioxidant capacity and phenolic contents using the FC method. This assay determines phenolic contents, which are not a measure of the antioxidant capacity of the sample, although they are related. However, this method should be used with caution as it can be influenced by the presence of other antioxidants and type of polyphenol (Apak et al., 2016; Prior, Wu, \& Schaich, 2005). Therefore, careful selection of one or more antioxidant assay can provide a broad interpretation of the antioxidant capacity of foods, provided that they were selected based on a predefined objective.

The radical-scavenging potential of functional components in food altered during NTP processing could be of benefit or disadvantageous. Such changes are particularly important for high-value foods with clear functional properties like prebiotic juices and whole F\&V. Table 2 presents a summary of literature related to the influence of NTP processing on antioxidant capacity and scavenging potential. The DPPH free radical-scavenging activity of high-voltage atmospheric cold plasma-treated grape juice declined by $10.66 \%$ following 4 min of treatment. In the same way, the antioxidant capacity was found to drop drastically in a similar time-dependent manner (Pankaj et al., 2017). Likewise, the effects of NTP and ozone on the antioxidant activity of prebiotic orange juice have also been investigated. DPPH showed no significant changes among the treated and untreated samples irrespective of the mode of exposure. Meanwhile, in the ABTS assay, a pronounced (50\% reduction) in the antioxidant activity with direct exposure at $60 \mathrm{~s}$ was recorded. It was hypothesized that the ABTS method was more responsive than the DPPH method be- cause of the reaction that occurred between the ABTS radicals and the antioxidant compounds in the juice. Unlike the NTP-treated juice, ozonated juice lost its antioxidant capacity by $18 \%$ when compared with the untreated. Although the dosage, $0.23 \mathrm{mg}$ $\mathrm{O}_{3} / \mathrm{mL}$, was far beyond the necessary dosage needed for pathogen inactivation (Almeida et al., 2015). The antioxidant activity of NTP-treated cashew apple juice using DPPH and ABTS was also reported. In both assays, the common trend was an increased antioxidant activity after a 5 -min treatment at an $\mathrm{N}_{2}$ flow rate of $10 \mathrm{~mL} / \mathrm{min}$. Following an increase in treatment time and $\mathrm{N}_{2}$ flow rate in the FRAP assay, the antioxidant activity was elevated, while a significant drop in antioxidant activity was observed in the DPPH assay. Therefore, low $\mathrm{N}_{2}$ plasma exposure at the lesser time led to an increased antioxidant activity, whereas extended treatment times and higher flow rates led to decline in the antioxidant activity. The influence on the antioxidant potential might be due to the higher vitamin C content in the juice (Rodríguez, Gomes, Rodrigues, \& Fernandes, 2017). An insignificant reduction in the antioxidant capacity of apple juice was reported following NTP exposure, however, a sharp decline was noticed with increasing the input power to $50 \mathrm{~W}$ for $30 \mathrm{~s}$ (Liao et al., 2018). During the exposure of radicchio leaves to NTP, an insignificant reduction in the antioxidant activity of the radicchio leaves was observed. The researchers, however, reported difficulty in investigating the plasma effect due to synergistic interactions of ROS, which might follow several reaction pathways (Pasquali et al., 2016).

Ramazzina and coresearcher used ABTS, DPPH, and FRAP assays to observe the effect of DBD plasma on the antioxidant activity and antioxidant contents of kiwifruit. The result showed no alteration in all the assays conducted after the NTP treatment. Generally, plasma-ROS should have caused oxidation of the phenolic compounds responsible for the antioxidant activity, however, due to the counteractive effect of the tissue response mechanisms in the kiwifruit, the ROS-induced oxidation was impeded (Ramazzina et al., 2015). The NTP treatment of fresh walnuts was found to have no effect on the antioxidant activity after $11 \mathrm{~min}$ of treatment. The FRAP and DPPH of the fresh walnuts were 233-240 and 226-240 $\mu \mathrm{mmol}$ TAE/g, respectively (Amini \& Ghoranneviss, 2016). A similar assertion was made for lettuce, in which antioxidant activity was insignificantly altered after exposure to NTP, regardless of assay type, power, treatment time, and type of gas used (Song et al., 2015). Another insignificant effect on the antioxidant capacity was observed in microwave-powered cold plasma-treated radish sprouts after $10 \mathrm{~min}$ of exposure at $900 \mathrm{~W}$ (Oh, Song, \& Min, 2017). Equally, the scavenging activity of plasma-treated mandarin flesh was not altered after exposure; however, that of the peel was significantly increased following the DPPH assay (Yeon et al., 2017). Similarly, the DPPH-scavenging activity of plasma-treated onion powder was increased from $80.71 \%$ to $84.94 \%$ after treatment at $400 \mathrm{~W}$ for $40 \mathrm{~min}$ (Kim et al., 2017). An alternative approach for delivering plasma-generated RS to the target is the use of PAW, which had recently been demonstrated to have significant antimicrobial activity (Figure 4). However, there are sparse data on the effects of PAW on the nutritional and functional properties of food products. One study reports the antioxidant capacity of button mushroom was extended with increases in PAW processing time. Among the processing times, the PAW-15 min treatment resulted in the highest antioxidant activity (47.25\%) (Xu, Tian, Ma, Liu, \& Zhang, 2016). Overall, most of the studies have restricted their research to either reporting an increase or decrease in the antioxidant potential of NTP-treated food. Further work is needed to clarify the 


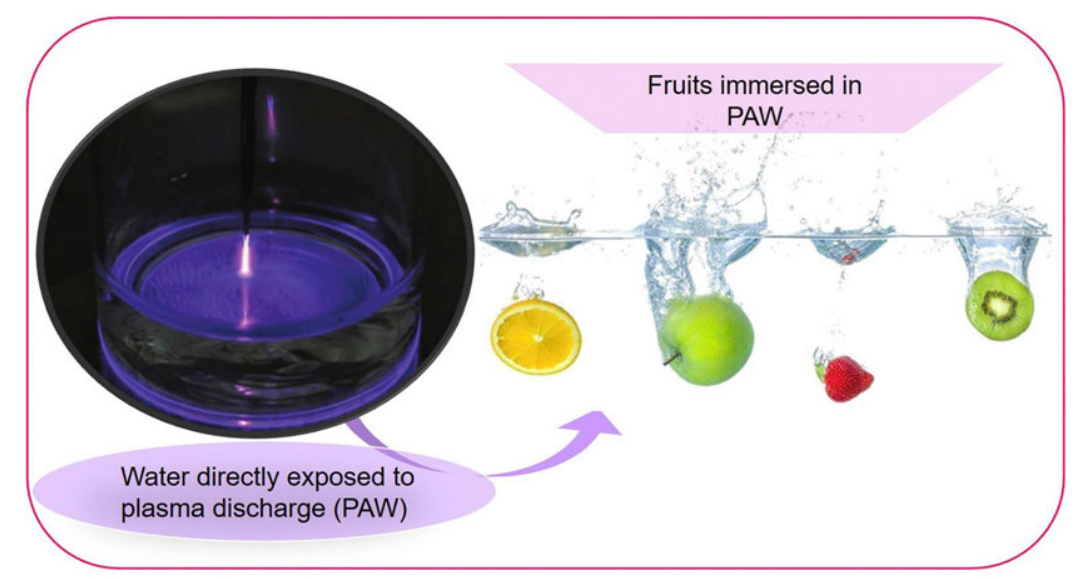

Figure 4-PAW generated from plasma exposure was used to immerse fruits for microbial inactivation.

reaction chemistry between plasma RS and antioxidants in food products.

\section{Influence of NTP on Vitamins}

The importance of $F \& V$ as sources of different kinds of antioxidants has been discussed; however, there are also natural sources of vitamins such as biotin, riboflavin (B2), and pyridoxine (B6) (Altemimi et al., 2017; Pankaj, Wan, \& Keener, 2018). These vitamins are usually stable. Others such as lycopene, carotenoids, vitamin $\mathrm{A}, \mathrm{C}$, and $\mathrm{E}$, and thiamin (B1) are liable to change during processing (Pankaj et al., 2018). Various researchers have reported NTP-induced effects on the concentrations and scavenging potential of vitamin C (Vc) (Aguiló-Aguayo et al., 2013; Bevilacqua et al., 2017; Bravo et al., 2012; Pankaj et al., 2018; Rodríguez et al., 2017). This might be connected to its antioxidant potential for the regulation of ROS and RNS via quenching their induced damage to the surrounding tissues and cells (Amatore, Arbault, Ferreira, Tapsoba, \& Verchier, 2008; Moldau, 1998).

Numerous articles report a positive effect of NTP processing on vitamins (Table 3). For instance, the Vc content of cashew juice was increased by $10.4 \%$ and $10.8 \%$ after 5 and 10 min NTP treatment, respectively. Upon increasing the $\mathrm{N}_{2}$ flow rate and treatment time, the Vc content declined (Rodríguez et al., 2017). Similarly, the ascorbic acid content in NTP-treated prebiotic orange juice was increased from $35.1 \pm 0.35 \mathrm{mg} / 100 \mathrm{~mL}$ to 41.11 \pm 0.33 (direct exposure) and $49.21 \pm 0.88 \mathrm{mg} / 100 \mathrm{~mL}$ (indirect exposure) after $60 \mathrm{~s}$ of treatment (Diva et al., 2017). The increment was attributed to various mechanisms, such as cell distortion, dissociation of smaller-sized particles, or due to chemical reactions induced by the action of ROS. The same group reported a similar increment in the same juice treated with high-pressure processing at $450 \mathrm{MPa}$ for $5 \mathrm{~min}$. Meanwhile, the ascorbic acid content of blueberries $(8.91 \mathrm{mg} / 100 \mathrm{~g})$ increased drastically to $14.01 \mathrm{mg} / 100 \mathrm{~g}$ following $1 \mathrm{~min}$ of NTP treatment at $80 \mathrm{kV}$. On extending the treatment time to $5 \mathrm{~min}$, the ascorbic acid content declined (Sarangapani et al., 2017). The treatment of button mushroom with PAW increased the concentration of Vc. However, the researchers did not give further details, only linking the increment to a postharvest storage of 7 days (Xu et al., 2016).

Yeon and co-researchers reported a distinct result after a whole mandarin was subjected to microwave cold plasma treatment. The ascorbic acid concentration in the flesh recorded an insignificant change, which ranged between 0.5 and $0.6 \mathrm{mg} / \mathrm{mL}$. Although this was linked to the level of energy applied, the presence of the thick mandarin peel might have shielded the target from the generated ROS (Yeon et al., 2017). Using similar plasma equipment, no reductions in the concentration of ascorbic acid was noticed after 10 min $900 \mathrm{~W}$ NTP treatment. Additionally, no accelerated degradation was observed during its storage at $4{ }^{\circ} \mathrm{C}$ and $10{ }^{\circ} \mathrm{C}$ (Oh et al., 2017). Irrespective of the NTP processing parameters (power, time, plasma gas), NTP-treated lettuce showed no significant effects on the concentration of ascorbic acid even after 12 days of storage (Song et al., 2015).

In contrast to the above results, a loss of $3.6 \%, 3.2 \%$, and $2.8 \%$ for cucumber, carrot, and pear slices was recorded, respectively, after NTP treatment (Wang et al., 2012). Another loss of Vc concentration was found for high-voltage atmospheric cold plasma-treated orange juice. The loss of concentration was a function of treatment time (Xu, Garner, Tao, \& Keener, 2017).

Looking at the aforementioned findings, it is evident that NTP had more positive than negative impacts on $\mathrm{V} c$. The critical factors found for ascorbic acid degradation are the food matrix, process gas, higher input power, and extended exposure times. Further studies on the influence of NTP on other vitamins is recommended.

\section{Effect of NTP Species and Their Toxicity}

ROS and RNS in NTP are the most important species generated for food applications. However, it is poorly understood which species could adversely cause health-related effects upon interaction with food matrices. Liao et al. (2018) reported increased concentrations of $\mathrm{O}_{3}, \mathrm{H}_{2} \mathrm{O}_{2}$, and nitrate with treatment time and power. The accumulation of nitrates and nitrites is a concern due to induced changes in cell viability (Tresp, Hammer, Weltmann, \& Reuter, 2013). Furthermore, ROS and RNS detected in PAW treated with helium gas plasma have resulted in significant effects on the rate of apoptosis (Chen, Lin, Cheng, Gjika, \& Keidar, 2016), while $\mathrm{H}_{2} \mathrm{O}_{2}$ and $\mathrm{O}_{2}{ }^{-}$produced have led to generation of $\mathrm{OH} \bullet$ in cells via the Haber-Weiss reaction, which resulted in apoptosis and cell death (Xu et al., 2015).

Similarly, plasma RS has induced chemical changes in food constituents, such as the modification of amino acid in proteins, oxidation of higher-molecular-weight compounds to organic acids, and lipids peroxidation, which could result in toxic metabolites 
like short-chain aldehydes (Muhammad et al., 2018). The only toxicity plasma research on edible film coatings conducted on rats reported very low toxicity in the edible films, which suggested that the plasma-treated films had no harmful byproducts (Han, Suh, Hong, Kim, \& Min, 2016).

Apart from the aforementioned, the potential rise in concentrations of nitrogen compounds in other food products, such as apple juice, needs in-depth analysis from researchers. Their concentration may exceed WHO standards such as $50 \mathrm{mg} / \mathrm{L}$ nitrate and $3 \mathrm{mg} / \mathrm{L}$ nitrite for drinking water, or the acceptable daily intake (ADI) of $222 \mathrm{mg} /$ day for a 60-kg adult (FAO/WHO, 2012). Therefore, more scientific approaches using both animals and human subjects are required to elucidate on the interactions with plasma RS.

\section{Disadvantages and Limitations of NTPT}

In spite of the immense contribution of NTP in various studies, its intricate RS chemistry is challenging in terms of regulatory approval and process validation. The abundant RS generated is already a complicated phenomenon, and their interactions with food materials become even more complex to understand because of the multicomponent nature of the food (starches, proteins, lipids, minerals, vitamins, and water). The reaction chemistry could be better predicted when these food components are studied in isolation (Muhammad et al., 2018). Moreover, the difficulty in the precise control of plasma reaction chemistry is worth mentioning due to the diverse moisture contents of foods (Coutinho et al., 2018). NTP treatment has caused increased lipid oxidation in high-fat foods such as walnut, peanuts, and milk, cheese, and oil after extended processing times. This was due to the oxidizing effect of radicals such as $\mathrm{OH} \bullet$ which might have oxidized the molecules of the lipids. Other detrimental effects were declined $\mathrm{pH}$, fruit firmness, and color, whereas increased acidity and formation of off-flavors were equally mentioned (Coutinho et al., 2018; Kim et al., 2015; Muhammad et al., 2018; Thirumdas et al., 2014). These are major concerns that need an exhaustive sensory evaluation for novel food processes.

Many studies have employed a variety of gases, such as argon, helium, or their combination with oxygen, as plasma process gas (Khani, Shokri, \& Khajeh, 2017; Kim et al., 2011; Rød, Hansen, Leipold, \& Knøchel, 2012). Irrespective of the gases used, both ROS and RNS will still be generated, even when the process gases do not contain either of $\mathrm{O}_{2}$ or $\mathrm{N}_{2}$ (Brandenburg et al., 2007). Economic analyses are also scarce; however, the technology could be affordable when atmospheric air is used as process gas instead of the expensive noble gases. Cullen et al. (2017) highlighted the likely approach to choose a cheaper alternative (air) for industrial scale-up looking at the large-scale volume encountered in food processing. The researchers stated that the limiting factor would be the dielectric strength of air $\left(3 \times 10^{6} \mathrm{~V} / \mathrm{m}\right)$, which requires high voltages to break down at atmospheric conditions (Cullen et al., 2017). Apart from the cost of the equipment design, all recurrent costs, including power and inducer gas, will probably help in estimating the operational cost. The rise in wattage consumed from the aboratory to industrial scale will be in accordance with size and capacity of the plasma equipment, ranging from watts to several thousand kilowatts. This should be compared to existing conventional and nonthermal technologies at the industrial level. For plasma systems, Niemira (2012) estimated the cost of power consumption in $\mathrm{kWh}$ as $\$ 0.05$. This implied that for every $1000 \mathrm{~h}$ of operation, $\$ 4500$ will be the approximate electricity cost.

\section{Conclusion and Recommendation}

Despite NTPT being at a nascent stage, it is rapidly gaining interest from researchers and industry alike. There have been numerous research studies focused on microbial inactivation, while less attention has been given to the effects on food components. This review highlights the complexity of plasma RS interactions with various bioactive compounds, antioxidants, and vitamins. Moreover, this article has explained the plasma chemistry as a driver of NTP enhancement of bioactive compounds and their antioxidant potentials. Other applications include improvements in polyphenol extraction and reductions in the required extraction times. Reaction chemistry is critical in NTP modification of functional food components, which are influenced by process conditions such as voltage, process gas, and treatment time. Oxidative degradation and double bond cleavage of polyphenols induced by ROS, such as $\mathrm{OH} \cdot \mathrm{O}_{3}$, and $\mathrm{O}_{2}{ }^{-}$, are the likely mechanisms that lead to the formation of compounds with carbonyl and carboxylic groups. There is a need for further elucidation of the interaction with polyphenols and vitamins, especially vitamins that have quenching effects against ROS and RNS-induced changes. Furthermore, a potential NTP interaction with AMPs for possible enhancement could be an interesting research topic that needs attention.

In addition, the establishment of safe NTP dosages (concentrations, treatment times, input power) at which toxic effects can occur on target food matrices is important. This might be difficult due to different plasma equipment configurations and the diverse moisture levels of food products. However, this can be achieved through process validation, optimization, and control to reduce the negative impacts on high-value food products such as $(\mathrm{F} \& \mathrm{~V})$, milk, meat, spices, and beverages. More in vivo studies to ascertain the toxicity of plasma-treated food materials are highly recommended as their safety is essential for regulatory approval for industrialization of the NTP technology.

\section{Nomenclature}

ABTS 2,2-azino-bis-3-ethylbenzthiazoline-6-sulfonic acid

ACP Atmospheric cold plasma

AMPs Antimicrobial peptides

Ar Argon

DBD Dielectric barrier discharge plasma

DPPH 2,2-diphenyl-1-picrylhydrazyl

FC Folin-Ciocalteu

FDA Food and Drugs Administration

F\&V Fruits and vegetables

FRAP ferric-reducing antioxidant power

$\mathrm{He} \quad$ Helium

$\mathrm{N} \quad$ Atomic nitrogen

$\mathrm{N}_{2} \quad$ Excited nitrogen

$\mathrm{Ne} \quad \mathrm{Neon}$

$\mathrm{NO} \cdot \quad$ Nitric oxide

NTP Nonthermal plasma

NTPT Nonthermal plasma technology

$\mathrm{O} \quad$ Atomic oxygen species

$\mathrm{O}_{2}^{-} \quad$ Superoxide anion

$\mathrm{O}_{2} \quad$ Molecular oxygen

${ }^{1} \mathrm{O}_{2} \quad$ Singlet oxygen

$\mathrm{OH}$ • Hydroxyl radical

$\mathrm{O}_{3} \quad$ Ozone

PAW Plasma activated water

RF Radio frequency

RNS Reactive nitrogen species

RS Plasma reactive species 
ROS Reactive oxygen species

TAC Total anthocyanins

TPC Total phenolic content

TFC Total flavonoid content

UV-C Ultraviolet irradiation

Vc Vitamin C

\section{Acknowledgments}

This study was supported by the Natl. Key R \& D Program of China (2017YFD0400403). The graduate study was funded by the China Scholarship Council under the Ministry of Education of the People's Republic of China.

\section{Conflict of Interest}

P. J. Cullen is CEO of a Plasma Technology Comp.; PlasmaLeap Technologies.

\section{Author Contributions}

Aliyu Idris Muhammad and Xinyu Liao drafted the manuscript. Patrick J. Cullen, Tian Ding, and Donghong Liu critically revised the article. Qisen Xiang, Shiguo Chen, and Xingqian Ye conceptualized the idea and drafted the outline.

\section{References}

Aadil, R. M., Zeng, X.-A., Han, Z., \& Sun, D. (2013). Effects of ultrasound treatments on quality of grapefruit juice. Food Chemistry, 141, 3201-3206. https://doi.org/10.1016/j.foodchem.2013.06.008

Abuajah, C. I., Ogbonna, A. C., \& Osuji, C. M. (2015). Functional components and medicinal properties of food: A review. Journal of Food Science and Technology, 52(5), 2522-2529.

https://doi.org/10.1007/s13197-014-1396-5

Aguiló-Aguayo, I., Charles, F., Renard, C. M. G. C., Page, D., \& Carlin, F. (2013). Pulsed light effects on surface decontamination, physical qualities and nutritional composition of tomato fruit. Postharvest Biology and Technology, 86, 29-36. https://doi.org/10.1016/j.postharvbio.2013.06.011

Aguiló-Aguayo, I., Gangopadhyay, N., Lyng, J. G., Brunton, N., \& Rai, D. K. (2017). Impact of pulsed light on colour, carotenoid, polyacetylene and sugar content of carrot slices. Innovative Food Science and Emerging Technologies, 42, 49-55. https://doi.org/10.1016/j.ifset.2017.05.006

Almeida, F. D. L., Cavalcante, R. S., Cullen, P. J., Frias, J. M., Bourke, P., Fernandes, F. A. N. N., \& Rodrigues, S. (2015). Effects of atmospheric cold plasma and ozone on prebiotic orange juice. Innovative Food Science and Emerging Technologies, 32, 127-135. https://doi.org/10.1016/j.ifset.2015.09.001

Altemimi, A., Lakhssassi, N., Baharlouei, A., Watson, D., \& Lightfoot, D. (2017). Phytochemicals: Extraction, isolation, and identification of bioactive compounds from plant extracts. Plants, 6(42), 1-23. https://doi.org/10.3390/plants6040042

Alves Filho, E. G., Cullen, P. J., Frias, J. M., Bourke, P., Tiwari, B. K., . . Fernandes, F. A. N. (2016). Evaluation of plasma, high-pressure and ultrasound processing on the stability of fructooligosaccharides. International Journal of Food Science and Technology, 51(9), 2034-2040. https://doi.org/10.1111/ijfs.13175

Amatore, C., Arbault, S., Ferreira, D. C. M., Tapsoba, I., \& Verchier, Y. (2008). Vitamin C stimulates or attenuates reactive oxygen and nitrogen species (ROS, RNS) production depending on cell state: Quantitative amperometric measurements of oxidative bursts at PLB-985 and RAW 264.7 cells at the single cell level. Journal of Electroanalytical Chemistry, 615(1), 34-44. https://doi.org/10.1016/j.jelechem.2007.11.037

Amini, M., \& Ghoranneviss, M. (2016). Effects of cold plasma treatment on antioxidants activity, phenolic contents and shelf life of fresh and dried walnut (Juglans regia L.) cultivars during storage. LWT - Food Science and Technology, 73, 178-184. https://doi.org/10.1016/j.lwt.2016.06.014

Apak, R., Özyürek, M., Güçlü, K., \& Çapanołlu, E. (2016). Antioxidant activity/capacity measurement. 1. Classification, physicochemical principles, mechanisms, and electron transfer (ET)-based assays. Journal of Agricultural and Food Chemistry, 64(5), 997-1027.

https://doi.org/10.1021/acs.jafc.5b04739
Bader, M. W., Sanowar, S., Daley, M. E., Schneider, A. R., Cho, U., Xu, W., Klevit, R. E., Le Moual, H., \& Miller, S. I. (2005). Recognition of antimicrobial peptides by a bacterial sensor kinase. Cell, 122, 461-472.

Bahar, A. A., \& Ren, D. (2013). Antimicrobial peptides. Pharmaceuticals, 6(12), 1543-1575. https://doi.org/10.3390/ph6121543

Bahram-Parvar, M., \& Lim, L. T. (2018). Fresh-cut onion: A review on processing, health benefits, and shelf-life. Comprehensive Reviews in Food Science and Food Safety, 17(2), 290-308.

https://doi.org/10.1111/1541-4337.12331

Bajpai, M., Mishra, A., \& Prakash, D. (2017). Antioxidant and free radical scavenging activities of some leafy vegetables. International Journal of Food Sciences and Nutrition, 56, 473-481.

https://doi.org/10.1080/09637480500524299

Barba, F. J., Mariutti, L. R. B., Bragagnolo, N., Mercadante, A. Z., Barbosa-Cánovas, G. V., \& Orlien, V. (2017). Bioaccessibility of bioactive compounds from fruits and vegetables after thermal and nonthermal processing. Trends in Food Science and Technology, 67, 195-206. https://doi.org/10.1016/j.tifs.2017.07.006

Bazaka, K., Jacob, M. V., Chrzanowski, W., \& Ostrikov, K. (2015). Anti-bacterial surfaces: Natural agents, mechanisms of action, and plasma surface modification. RSC Advances, 5(60), 48739-48759. https://doi.org/10.1039/C4RA17244B

Bevilacqua, A., Petruzzi, L., Perricone, M., Speranza, B., Campaniello, D., Sinigaglia, M., \& Corbo, M. R. (2017). Nonthermal technologies for fruit and vegetable juices and beverages: Overview and advances. Comprehensive Reviews in Food Science and Food Safety, 17,

https://doi.org/10.1111/1541-4337.12299

Bommarius, B., Jenssen, H., Elliott, M., Kindrachuk, J., Pasupuleti, M., Gieren, H., Jaeger, K. E., Hancock, R. E., \& Kalman, D. (2010). Cost-effective expression and purification of antimicrobial and host defense peptides in Escherichia coli. Peptides, 31, 1957-1965.

Brandenburg, R., Ehlbeck, J., Stieber, M., Woedtke, T. V., Zeymer, J., Schlüter, O., \& Weltmann, K. D. (2007). Antimicrobial treatment of heat sensitive materials by means of atmospheric pressure $\mathrm{R} f$-driven plasma jet. Contributions to Plasma Physics, 47(1-2), 72-79. https://doi.org/10.1002/ctpp.200710011

Bravo, S., García-Alonso, J., Martín-Pozuelo, G., Gómez, V., Santaella, M., Navarro-González, I., \& Periago, M. J. (2012). The influence of post-harvest UV-C hormesis on lycopene, $\beta$-carotene, and phenolic content and antioxidant activity of breaker tomatoes. Food Research International, 49, https://doi.org/10.1016/j.foodres.2012.07.018

Brogden, K. A. (2005). Antimicrobial peptides: Pore formers or metabolic inhibitors in bacteria? Nature Reviews Microbiology, 3(3), 238-250. https://doi.org/10.1038/nrmicro1098

Buchner, N., Krumbein, A., Rohn, S., \& Kroh, L. W. (2006). Effect of thermal processing on the flavonols rutin and quercetin. Rapid Communications in Mass Spectrometry : RCM, 20(24), 3229-3235. https://doi.org/10.1002/rcm

Bußler, S., Herppich, W. B., Neugart, S., Schreiner, M., Ehlbeck, J., Rohn, S., \& Schlüter, O. (2015). Impact of cold atmospheric pressure plasma on physiology and flavonol glycoside profile of peas (Pisum sativum 'Salamanca'). Food Research International, 76, 132-141. https://doi.org/10.1016/j.foodres.2015.03.045

Cano, M. P., Hernandez, A., \& Ancos, B. (1997). High pressure and temperature effects on enzyme inactivation in strawberry and orange products. Journal of Food Science, 62(1), 85-88. https://doi.org/10.1111/j.1365-2621.1997.tb04373.x

Chen, Z., Lin, L., Cheng, X., Gjika, E., \& Keidar, M. (2016). Effects of cold atmospheric plasma generated in deionized water in cell cancer therapy. Plasma Processes and Polymers, 13(12), 1151-1156. https://doi.org/10.1002/ppap.201600086

Chiang, M. H., Wu, J. Y., Li, Y. H., Wu, J. S., Chen, S. H., \& Chang, C. L. (2010). Inactivation of E. coli and B. subtilis by a parallel-plate dielectric barrier discharge jet. Surface and Coatings Technology, 204(21-22), 3729-3737. https://doi.org/10.1016/j.surfcoat.2010.04.057

Cleveland, J., Montville, T. J., Nes, I. F., \& Chikindas, M. L. (2001). Bacteriocins: Safe, natural antimicrobials for food preservation. International Journal of Food Microbiology, 71(1), 1-20. https://doi.org/10.1016/S0168-1605(01)00560-8

Coutinho, N. M., Silveira, M. R., Rocha, R. S., Moraes, J., Ferreira, M. V. S., Pimentel, T. C., ... Cruz, A. G. (2018). Cold plasma processing of milk and dairy products. Trends in Food Science and Technology, 74, 56-68. https://doi.org/10.1016/j.tifs.2018.02.008 
Craig, W. J. (1997). Phytochemicals: Guardians of our health. Journal of the American Dietetic Association, 97(10), S199-S204. https://doi.org/10.1016/S0002-8223(97)00765-7

Criegee. (1957). Mechanism of ozonolysis. Angewandte Chemie International Edition, 14(11), 745-752.

Cullen, P. J., Milosavljevi, V., Lalor, J., Scally, L., Boehm, D., Bourke, P., \& Keener, K. (2017). Translation of plasma technology from the lab to the food industry. Plasma Processes and Polymers, 1-11. https://doi.org/10.1002/ppap.201700085

Dasan, B. G., \& Boyaci, I. H. (2018). Effect of cold atmospheric plasma on inactivation of Escherichia coli and physicochemical properties of apple, orange, tomato juices, and sour cherry nectar. Food Bioprocess Technology, 11(2), 1-10. https://doi.org/https://doi.org/10.1007/s11947-017-2014-0

Diva, F., Almeida, L., Faria, W., Souza, R., Tiwari, B. K., Cullen, P. J., . . Rodrigues, S. (2017). Fructooligosaccharides integrity after atmospheric cold plasma and high- pressure processing of a functional orange juice. Food Research International, 102, 282-290.

https://doi.org/10.1016/j.foodres.2017.09.072

Dong, S., Gao, A., Xu, H., \& Chen, Y. (2017). Effects of dielectric barrier discharges (DBD) cold plasma treatment on physicochemical and structural properties of zein powders. Food Bioprocess Technology, 10, 434-444. https://doi.org/10.1007/s11947-016-1814-y

Eckert, R., Qi, F., Yarbrough, D. K., He, J., Anderson, M. H., \& Shi, W (2006). Adding selectivity to antimicrobial peptides: Rational design of a multidomain peptide against Pseudomonas spp. Antimicrobial Agents and Chemotherapy, 50, 1480-1488.

Ekezie, F. C., Sun, D.-W., \& Cheng, J.-H. (2017). A review on recent advances in cold plasma technology for the food industry: Current applications and future trends. Trends in Food Science \& Technology, 69, 46-58. https://doi.org/10.1016/j.tifs.2017.08.007

FAO/WHO. (2012). Evaluation of certain food additives. Fifty-ninth report of the joint FAO/WHO expert committee on food additives. Joint FAO/WHO Expert Committee on Food Additives (JECFA publications) Geneva.

Fernández, A., Noriega, E., \& Thompson, A. (2013). Inactivation of Salmonella enterica serovar Typhimurium on fresh produce by cold atmospheric gas plasma technology. Food Microbiology, 33(1), 24-29. https://doi.org/10.1016/j.fm.2012.08.007

Fernández, A., Shearer, N., Wilson, D. R., \& Thompson, A. (2012). Effect of microbial loading on the efficiency of cold atmospheric gas plasma inactivation of Salmonella enterica serovar Typhimurium. International Journal of Food Microbiology, 152(3), 175-180.

https://doi.org/10.1016/j.ijfoodmicro.2011.02.038

Fridman, A. (2008). Plasma chemistry, Cambridge university press, New York https://doi.org/10.1017/CBO9780511546075

Fridman, G., Brooks, A. D., Balasubramanian, M., Fridman, A., Gutsol, A., Vasilets, V. N., ... Friedman, G. (2007). Comparison of direct and indirect effects of plasma on bacteria. Plasma Processes and Polymers, 4, 370-375. https://doi.org/10.1002/ppap.200600217

Galanakis, C. M. (2017). Nutraceutical and functional food components: Effects of innovative processing techniques. In M. Ball (Ed.), London: Elsevier Academic Press.

Gallagher, J. M. Jr., Vaze, N., Gangoli, S., Vasilets, V. N., Gutsol, A. F., .. Fridman, A. A. (2007). Rapid inactivation of airborne bacteria using atmospheric pressure dielectric barrier discharge. IEEE Transactions on Plasma Science, 35(5), 1501-1510. https://doi.org/10.1109/TPS.2007.905209 Garofulić, I. E., Režek Jambrak, A., Milošević, S., Dragović-Uzelac, V., Zorić, Z., \& Herceg, Z. (2015). The effect of gas phase plasma treatment on the anthocyanin and phenolic acid content of sour cherry Marasca (Prunus cerasus var. Marasca) juice. LWT - Food Science and Technology, 62(1), 894-900. https://doi.org/10.1016/j.lwt.2014.08.036

Ghrairi, T., Chaftar, N., \& Hani, K. (2012). Bacteriocins: recent advances and opportunities. In R. Bhat, A. Karim-Alias, \& G. Paliyath (Eds.), Progress in Food Preservation (pp. 485-511). Oxford: Wiley-Blackwell.

Gil, M. I., Aguayo, E., \& Kader, A. A. (2006). Quality changes and nutrient retention in fresh-cut versus whole fruits during storage. Journal of Agricultural and Food Chemistry, 54(12), 4284-4296.

https://doi.org/10.1021/jf060303y

Gironés-Vilaplana, A., Huertas, J. P., Moreno, D. A., Periago, P. M., \& García-Viguera, C. (2016). Quality and microbial safety evaluation of new isotonic beverages upon thermal treatments. Food Chemistry, 194, 455-462. https://doi.org/10.1016/j.foodchem.2015.08.011

Grzegorzewski, F., Ehlbeck, J., Schlüter, O., Kroh, L. W., \& Rohn, S. (2011a). Treating lamb's lettuce with a cold plasma-influence of atmospheric pressure Ar plasma immanent species on the phenolic profile of
Valerianella locusta. LWT - Food Science and Technology, 44(10), 2285-2289. https://doi.org/10.1016/j.lwt.2011.05.004

Grzegorzewski, F., Zietz, M., Rohn, S., Kroh, L.W. \& Schlueter, O. (2011b) Modification of polyphenols and cuticular surface lipids of Kale (B. oleracea convar. sabellica) with non-thermal oxygen plasma gaseous species. The 11th International Congress on Engineering and Food, Athens, Greece.

Grzegorzewski, F., Rohn, S., Kroh, L. W., Geyer, M., \& Schlüter, O.

(2010a). Surface morphology and chemical composition of lamb's lettuce

(Valerianella locusta) after exposure to a low-pressure oxygen plasma. Food Chemistry, 122(4), 1145-1152.

https://doi.org/10.1016/j.foodchem.2010.03.104

Grzegorzewski, F., Rohn, S., Quade, A., Schröder, K., Ehlbeck, J., Schlüter, O., \& Kroh, L. W. (2010b). Reaction chemistry of 1,4-benzopyrone derivates in non-equilibrium low-temperature plasmas. Plasma Processes and Polymers, 7(6), 466-473. https://doi.org/10.1002/ppap.200900140

Grzegorzewski, F, Schlüter, O., Ehlbeck, J., Weltmann, K. D., Geyer, M., Kroh, L. W., \& Rohn, S. (2009). Plasma-oxidative degradation of polyphenolics - influence of non-thermal gas discharges with respect to fresh produce processing. Czech Journal of Food Sciences, 27(SPEC. ISS.), 35-39.

Han, S. H., Suh, H. J., Hong, K. B., Kim, S. Y., \& Min, S. C. (2016). Oral toxicity of cold plasma-treated edible films for food coating. Journal of Food Science, 81(12), T3052-T3057. https://doi.org/10.1111/1750-3841.13551

Harry, J. (2010). Introduction to plasma technology: Science, engineering and applications. Weinheim, Germany: WILEY-VCH Verlag \& Co. KGaA https://doi.org/10.1002/9783527632169

Harry, J. E. (2010). Introduction to plasma technology-Science, engineering and applications. Weinheim, Germany: Wiley-VCH.

https://doi.org/10.1002/9783527632169

Herceg, Z., Kovačević, D. B., Kljusurić, J. G., Jambrak, A. R., Zorić, Z., \& Dragović-Uzelac, V. (2016). Gas phase plasma impact on phenolic compounds in pomegranate juice. Food Chemistry, 190, 665-672.

https://doi.org/10.1016/j.foodchem.2015.05.135

Howard, L. A., Jeffery, E. H., Wallig, M. A., \& Klein, B. P. (1997). Retention of phytochemicals in fresh and processed broccoli. Journal of Food Science, 62(6), 1098-1104. https://doi.org/10.1111/j.1365-2621.1997.tb12221.x

Idehen, E., Tang, Y., \& Sang, S. (2016). Bioactive phytochemicals in barley.

Journal of Food and Drug Analysis, 1-14.

https://doi.org/10.1016/j.jfda.2016.08.002

Izadpanah, A., \& Gallo, R. L. (2005). Antimicrobial peptides. Journal of the American Academy of Dermatology, 52(3), 381-390. https://doi.org/10.1016/j.jaad.2004.08.026

Joubert, V., Cheype, C., Bonnet, J., Packan, D., Garnier, J. P., Teissié, J., \& Blanckaert, V. (2013). Inactivation of Bacillus subtilis var. niger of both spore and vegetative forms by means of corona discharges applied in water. Water Research, 47(3), 1381-1389. https://doi.org/10.1016/j.watres.2012.12. 011

Khani, M. R., Shokri, B., \& Khajeh, K. (2017). Studying the performance of dielectric barrier discharge and gliding arc plasma reactors in tomato peroxidase inactivation. Journal of Food Engineering, 197, 107-112. https://doi.org/10.1016/j.jfoodeng.2016.11.012

Kim, B., Yun, H., Jung, S., Jung, Y., Jung, H., Choe, W., \& Jo, C. (2011). Effect of atmospheric pressure plasma on inactivation of pathogens inoculated onto bacon using two different gas compositions. Food Microbiology, 28(1), 9-13. https://doi.org/10.1016/j.fm.2010.07.022

Kim, H. J., Yong, H. I., Park, S., Kim, K., Choe, W., \& Jo, C. (2015). Microbial safety and quality attributes of milk following treatment with atmospheric pressure encapsulated dielectric barrier discharge plasma. Food Control, 47, 451-456. https://doi.org/10.1016/j.foodcont.2014.07.053

Kim, J. E., Oh, Y. J., Won, M. Y., Lee, K. S., \& Min, S. C. (2017). Microbial decontamination of onion powder using microwave-powered cold plasma treatments. Food Microbiology, 62, 112-123.

https://doi.org/10.1016/j.fm.2016.10.006

Kobzev, E. N., Kireev, G. V., Rakitskii, Y. A., Martovetskaya, I. I., Chugunov, V. A., Kholodenko, V. P., .. . Grushin, M. E. (2013). Effect of cold plasma on the E. coli cell wall and plasma membrane. Applied Biochemistry and Microbiology, 49(2), 144-149. https://doi.org/10.1134/S0003683813020063

Kongkachuichai, R., Charoensiri, R., Yakoh, K., Kringkasemsee, A., \& Insung, P. (2015). Nutrients value and antioxidant content of indigenous vegetables from southern Thailand. Food Chemistry, 173, 836-846. https://doi.org/10.1016/j.foodchem.2014.10.123

Korachi, M., Gurol, C., \& Aslan, N. (2010). Atmospheric plasma discharge sterilization effects on whole cell fatty acid profiles of Escherichia coli and 
Staphylococcus aureus. Journal of Electrostatics, 68(6), 508-512. https://doi.org/10.1016/j.elstat.2010.06.014

Kostov, K. G., Rocha, V., Koga-Ito, C. Y., Matos, B. M., Algatti, M. A., Honda, R. Y., ... Mota, R. P. (2010). Bacterial sterilization by a dielectric barrier discharge (DBD) in air. Surface and Coatings Technology, 204(18-19), 2954-2959. https://doi.org/10.1016/j.surfcoat.2010.01.052

Kovačević, D. B., Kljusurić, J. G., Putnik, P., Vukušić, T., Herceg, Z., \& Dragović-Uzelac, V. (2016a). Stability of polyphenols in chokeberry juice treated with gas phase plasma. Food Chemistry, 212, 323-331. https://doi.org/10.1016/j.foodchem.2016.05.192

Kovačević, D. B., Putnik, P., Dragović-Uzelac, V., Pedisić, S., Režek Jambrak, A., \& Herceg, Z. (2016b). Effects of cold atmospheric gas phase plasma on anthocyanins and color in pomegranate juice. Food Chemistry, 190, 317-323. https://doi.org/10.1016/j.foodchem.2015.05.099

Kristbergsson, K., \& Ötles, S. (2016). Functional properties of traditional foods. In K. Kristbergsson \& S. Ötles (Eds.). New York: Springer Science Business Media, LLC. https://doi.org/10.1007/978-1-4899-7662-8

Lacombe, A., Niemira, B. A., Gurtler, J. B., Fan, X., Sites, J., Boyd, G., \& Chen, H. (2015). Atmospheric cold plasma inactivation of aerobic microorganisms on blueberries and effects on quality attributes. Food Microbiology, 46, 479-484. https://doi.org/10.1016/j.fm.2014.09.010

Lancaster, L. E., Wintermeyer, W., \& Rodnina, M. V. (2007). Colicins and their potential in cancer treatment. Blood Cells Molecules Diseases, 38, 15-18. https://doi.org/10.1016/j.bcmd.2006.10.006

Landbo, A. K., \& Meyer, A. S. (2001). Enzyme-assisted extraction of antioxidative phenols from black currant juice press residues (Ribes nigrum). Journal of Agricultural and Food Chemistry, 49(7), 3169-3177. https://doi.org/10.1021/jf001443p

Laroussi, M., \& Leipold, F. (2004). Evaluation of the roles of reactive species, heat, and UV radiation in the inactivation of bacterial cells by air plasmas at atmospheric pressure. International Journal of Mass Spectrometry, 233(1-3), 81-86. https://doi.org/10.1016/j.ijms.2003.11.016

Laroussi, M., Mendis, D. A., \& Rosenberg, M. (2003). Plasma interaction with microbes. New Journal of Physics, 5 ,

https://doi.org/10.1088/1367-2630/5/1/341

Liao, X., Li, J., Muhammad, A. I., Suo, Y., Chen, S., Ye, X., ... Ding, T. (2018). Application of a dielectric barrier discharge atmospheric cold Plasma (Dbd-Acp) for Eshcerichia coli inactivation in apple juice. Journal of Food Science, 83(2), 401-408. https://doi.org/10.1111/1750-3841.14045

Liao, X., Liu, D., Xiang, Q., Ahn, J., Chen, S., Ye, X., \& Ding, T. (2017a). Inactivation mechanisms of non-thermal plasma on microbes: A review. Food Control, 75, 83-91. https://doi.org/10.1016/j.foodcont.2016.12.021

Liao, X., Xiang, Q., Liu, D., Chen, S., Ye, X., \& Ding, T. (2017b). Lethal and sublethal effect of a dielectric barrier discharge atmospheric cold plasma on Staphylococcus aureus. Journal of Food Protection, 80(6), 928-932. https://doi.org/10.4315/0362-028X.JFP-16-499

Liao, X., Muhammad, A. I., Chen, S., Hu, Y., Ye, X., Liu, D., \& Ding, T. (2018). Bacterial spore inactivation induced by cold plasma. Critical Reviews in Food Science and Nutrition, 00(00), 1-11. https://doi.org/10.1080/10408398.2018.1460797

Liu, R. H. (2007). Whole grain phytochemicals and health. Journal of Cereal Science, 46(3), 207-219. https://doi.org/10.1016/j.jcs.2007.06.010

Liu, R. H. (2013). Dietary bioactive compounds and their health implications. Journal of Food Science, 78(S1), A18-A25. https://doi.org/10.1111/1750-3841.12101

Lotfy, K. (2017). Cold plasma jet construction to use in medical, biology and polymer applications. Journal of Modern Physics, 08(11), 1901-1910. https://doi.org/10.4236/jmp.2017.811113

Lu, X., Jiang, Z., Xiong, Q., Tang, Z., Hu, X., \& Pan, Y. (2008). An $11 \mathrm{~cm}$ long atmospheric pressure cold plasma plume for applications of plasma medicine. Applied Physics Letters, 92(8), 2006-2008.

https://doi.org/10.1063/1.2883945

Lu, X., Laroussi, M., \& Puech, V. (2012). On atmospheric-pressure non-equilibrium plasma jets and plasma bullets. Plasma Sources Science and Technology, 21, 1-17. https://doi.org/10.1088/0963-0252/21/3/034005

Ma, R., Wang, G., Tian, Y., Wang, K., Zhang, J., \& Fang, J. (2015). Non-thermal plasma-activated water inactivation of food-borne pathogen on fresh produce. Journal of Hazardous Materials, 300, 643-651. https://doi.org/10.1016/j.jhazmat.2015.07.061

Makris, D. P., \& Rossiter, J. T. (2002). Hydroxyl free radical-mediated oxidative degradation of quercetin and morin: A preliminary investigation. Journal of Food Composition and Analysis, 15(1), 103-113.

https://doi.org/10.1006/jfca.2001.1030
Mann, N. (2011). Phytochemicals. Nutrition, 56(2), 97-99.

https://doi.org/10.1016/j.denabs.2010.08.033

Matan, N., Puangjinda, K., Phothisuwan, S., \& Nisoa, M. (2015). Combined antibacterial activity of green tea extract with atmospheric radio-frequency plasma against pathogens on fresh-cut dragon fruit. Food Control, 50, 291-296. https://doi.org/10.1016/j.foodcont.2014.09.005

Mir, S. A., Shah, M. A., \& Mir, M. M. (2016). Understanding the role of plasma technology in food industry. Food and Bioprocess Technology, 1-17. https://doi.org/10.1007/s11947-016-1699-9

Misra, N. N., Kaur, S., Tiwari, B. K., Kaur, A., Singh, N., \& Cullen, P. J. (2015). Atmospheric pressure cold plasma (ACP) treatment of wheat flour. Food Hydrocolloids, 44, 115-121.

https://doi.org/10.1016/j.foodhyd.2014.08.019

Misra, N. N., Keener, K. M., Bourke, P., Mosnier, J., \& Cullen, P. J. (2014). In-package atmospheric pressure cold plasma treatment of cherry tomatoes. Journal of Bioscience and Bioengineering, 118(2), 177-182.

https://doi.org/10.1016/j.jbiosc.2014.02.005

Misra, N. N., Schlüter, O. K., \& Cullen, P. J. (2016). Cold plasma in food and agriculture: Fundamentals and applications. In P. Osborn (Ed.) (First). United Kingdom: Elsevier Academic Press.

Misra, N. N., Tiwari, B. K., Raghavarao, K. S. M. S., \& Cullen, P. J. (2011). Nonthermal plasma inactivation of food-borne pathogens. Food Engineering Reviews, 3, 159-170. https://doi.org/10.1007/s12393-011-9041-9

Moldau, H. (1998). Hierarchy of ozone scavenging reactions in the plant cell wall. Physiologia Plantarum, 104, 617-622.

https://doi.org/10.1034/j.1399-3054.1998.1040414.x

Moreau, M., Feuilloley, M. G. J., Veron, W., Meylheuc, T., Chevalier, S., Brisset, J. L., \& Orange, N. (2007). Gliding arc discharge in the potato pathogen Erwinia carotovora subsp. atroseptica: Mechanism of lethal action and effect on membrane-associated molecules. Applied and Environmental Microbiology, 73(18), 5904-5910. https://doi.org/10.1128/AEM.00662-07

Muhammad, A. I., Xiang, Q., Liao, X., Liu, D., \& Ding, T. (2018).

Understanding the impact of nonthermal plasma on food constituents and microstructure - A review. Food and Bioprocess Technology, 11(3), 463-486. https://doi.org/https://doi.org/10.1007/s11947-017-2042-9

Ni, Y., Lynch, M. J., Modic, M., Whalley, R. D., \& Walsh, J. L. (2016). A solar powered handheld plasma source for microbial decontamination applications. Journal of Physics D: Applied Physics, 49(35), 355203. https://doi.org/10.1088/0022-3727/49/35/355203

Niemira, B. A. (2012). Cold plasma decontamination of foods. Annual Review of Food Science and Technology, 3(1), 125-142.

https://doi.org/10.1146/annurev-food-022811-101132

Niki, E., \& Noguchi, N. (2000). Evaluation of antioxidant capacity. What capacity is being measured by which method? IUBMB Life, 50(4-5), 323-329. https://doi.org/10.1080/15216540051081119

Noomhorm, A., Ahmad, I., \& Anal, A. K. (2014). Functional foods and dietary supplements: Processing effects and health benefits (1st ed.). In A. Noomhorm, I. Ahmad, \& A. K. Anal (Eds.). United Kingdom: Wiley Blackwell. https://doi.org/10.1002/9781118227800

Oh, Y. J., Song, A. Y., \& Min, S. C. (2017). Inhibition of Salmonella typhimurium on radish sprouts using nitrogen-cold plasma. International Journal of Food Microbiology, 249, 66-71.

https://doi.org/10.1016/j.ijfoodmicro.2017.03.005

Pacor, S., Giangaspero, A., Bacac, M., Sava, G., \& Tossi, A. (2002). Analysis of the cytotoxicity of synthetic antimicrobial peptides on mouse leucocytes: Implications for systemic use. Journal of Antimicrobial Chemotherapy, 50, 339-348.

Pankaj, S. K., Bueno-ferrer, C., Misra, N. N., Bourke, P., \& Cullen, P. J. (2014). Zein film : Effects of dielectric barrier discharge atmospheric cold plasma. Journal of Applied Polymer Science, 1-6.

https://doi.org/10.1002/app.40803

Pankaj, S. K., Bueno-Ferrer, C., Misra, N. N., O’Neill, L., Tiwari, B. K., Bourke, P., \& Cullen, P. J. (2015). Dielectric barrier discharge atmospheric air plasma treatment of high amylose corn starch films. LWT - Food Science and Technology, 63(2), 1076-1082.

https://doi.org/10.1016/j.lwt.2015.04.027

Pankaj, S. K., \& Keener, K. M. (2017). Cold plasma: Background, applications and current trends. Current Opinion in Food Science, 16, 49-52. https://doi.org/10.1016/j.cofs.2017.07.008

Pankaj, S. K., \& Keener, K. M. (2018). Cold plasma processing of fruit juices. In G. Rajauria \& B. K. Tiwari (Eds.), Fruit juices-Extraction, composition, quality and analysis (1st, pp. 529-537). Elsevier Inc, Cambridge, Massachusetts. https://doi.org/10.1016/B978-0-12-802230-6.00026-6 
Pankaj, S. K., Misra, N. N., \& Cullen, P. J. (2013). Kinetics of tomato peroxidase inactivation by atmospheric pressure cold plasma based on dielectric barrier discharge. Innovative Food Science and Emerging Technologies, 19, 153-157. https://doi.org/10.1016/j.ifset.2013. $\underline{03.001}$

Pankaj, S. K., Wan, Z., Colonna, W., \& Keener, K. M. (2017). Effect of high voltage atmospheric cold plasma on white grape juice quality. Journal of the Science of Food and Agriculture, 97, 4016-4021.

https://doi.org/10.1002/jsfa.8268

Pankaj, S. K., Wan, Z., \& Keener, K. M. (2018). Effects of cold plasma on food quality: A review. Foods, 7(1), 4. https://doi.org/10.3390/foods7010004

Park, C. B., Kim, H. S., \& Kim, S. C. (1998). Mechanism of action of the antimicrobial peptide buforin II: Buforin II kills microorganisms by penetrating the cell membrane and inhibiting cellular functions. Biochemical and Biophysical Research Communications, 244(1), 253-257.

https://doi.org/10.1006/bbrc.1998.8159

Pasquali, F., Stratakos, A. C., Koidis, A., Berardinelli, A., Cevoli, C., Ragni, L., .. Trevisani, M. (2016). Atmospheric cold plasma process for vegetable leaf decontamination: A feasibility study on radicchio (red chicory, Cichorium intybus L.). Food Control, 60, 552-559. https://doi.org/10.1016/j.foodcont.2015.08.043

Patras, A., Brunton, N. P., O’Donnell, C., \& Tiwari, B. K. (2010). Effect of thermal processing on anthocyanin stability in foods; mechanisms and kinetics of degradation. Trends in Food Science and Technology, 21(1), 3-11. https://doi.org/10.1016/j.tifs.2009.07.004

Pignata, C., Angelo, D. D., Fea, E., \& Gilli, G. (2017). A review on microbiological decontamination of fresh produce with nonthermal plasma. Journal of Applied Microbiology, 122, 1438-1455.

https://doi.org/10.1111/jam.13412

Pinela, J., \& Ferreira, I. C. F. R. (2017). Nonthermal physical technologies to decontaminate and extend the shelf-life of fruits and vegetables: Trends aiming at quality and safety. Critical Reviews in Food Science and Nutrition, 57(10), 2095-2111. https://doi.org/10.1080/10408398.2015. 1046547

Prior, R. L., Wu, X., \& Schaich, K. (2005). Standardized methods for the determination of antioxidant capacity and phenolics in foods and dietary supplements. Journal of Agricultural and Food Chemistry, 53, 4290-4302.

Ramazzina, I., Berardinelli, A., Rizzi, F., Tappi, S., Ragni, L., Sacchetti, G., \& Rocculi, P. (2015). Effect of cold plasma treatment on physico-chemical parameters and antioxidant activity of minimally processed kiwifruit. Postharvest Biology and Technology, 107, 55-65. https://doi.org/10.1016/j.postharvbio.2015.04.008

Rød, S. K., Hansen, F., Leipold, F., \& Knøchel, S. (2012). Cold atmospheric pressure plasma treatment of ready-to-eat meat: Inactivation of Listeria innocua and changes in product quality. Food Microbiology, 30(1), 233-238. https://doi.org/10.1016/j.fm.2011.12.018

Røssland, E., Langsrud, T., Granum, P. E., - Sørhaug, T. (2005). Production of antimicrobial metabolites by strains of Lactobacillus or Lactococcus co-cultured with Bacillus cereus in milk. International Journal of Food Microbiology, 98(2), 193-200.

https://doi.org/10.1016/j.ijfoodmicro.2004.06.003

Rodríguez, Ó., Gomes, W. F., Rodrigues, S., \& Fernandes, F. A. N. (2017). Effect of indirect cold plasma treatment on cashew apple juice (Anacardium occidentale L.). LWT - Food Science and Technology, 84, 457-463. https://doi.org/10.1016/j.lwt.2017.06.010

Roth, J. R. (1995). Industrial plasma engineering (Vol. 1). Bristol and Philadelphia: IOP Publishing Ltd.

Sarangapani, C., O’Toole, G., Cullen, P. J., \& Bourke, P. (2017).

Atmospheric cold plasma dissipation efficiency of agrochemicals on

blueberries. Innovative Food Science and Emerging Technologies, 44, 235-241. https://doi.org/10.1016/j.ifset.2017.02.012

Sarangapani, C., Patange, A., Bourke, P., Keener, K., \& Cullen, P. J. (2018). Recent advances in the application of cold plasma technology in foods. Annual Review of Food Science and Technology, 9, 609-629.

Sarangapani, C., Thirumdas, R., Devi, Y., Trimukhe, A., Deshmukh, R. R., \& Annapure, U. S. (2016). Effect of low-pressure plasma on physico-chemical and functional properties of parboiled rice flour. $L W T$ Food Science and Technology, 69(1), 482-489.

https://doi.org/10.1016/j.lwt.2016.02.003

Scalbert, A., Johnson, I. T., \& Saltmarsh, M. (2005). Polyphenols: Antioxidants and beyond. The American Journal of Clinical Nutrition, 81(suppl), 215S-217S. Retrieved from https://doi.org/81/1/215S [pii]
Schlüter, O., \& Fröhling, A. (2014). Cold plasma for bioefficient food processing. Encyclopedia of Food Microbiology, 2, 948-953. https://doi.org/10.1016/B978-0-12-384730-0.00402-X

Scholtz, V., Pazlarova, J., Souskova, H., Khun, J., \& Julak, J. (2015).

Nonthermal plasma - A tool for decontamination and disinfection. Biotechnology Advances, 33(6), 1108-1119.

https://doi.org/10.1016/j.biotechadv.2015.01.002

Schreiner, M., \& Huyskens-Keil, S. (2006). Phytochemicals in fruit and vegetables: Health promotion and postharvest elicitors. Critical Reviews in Plant Sciences, 25(3), 267-278.

https://doi.org/10.1080/07352680600671661

Shai, Y. (2002). Mode of action of membrane active antimicrobial peptides. Biopolymers, 236-248.

Siddiq, M., Ahmed, J., Lobo, G. M., \& Ozadali, F. (2012). Tropical and subtropical fruits: Processing and packaging tropical and subtropical fruits. In J. Ahmed, G. M. Lobo, \& F. Ozadali (Eds.) (first). UK: Wiley Blackwell.

Smet, C., Noriega, E., Rosier, F., Walsh, J. L., Valdramidis, V. P., \& Van Impe, J. F. (2017). Impact of food model (micro)structure on the microbial inactivation efficacy of cold atmospheric plasma. International Journal of Food Microbiology, 240, 47-56

https://doi.org/10.1016/j.ijfoodmicro.2016.07.024

Song, A. Y., Oh, Y. J., Kim, J. E., Song, K. Bin, Oh, D. H., \& Min, S. C.

(2015). Cold plasma treatment for microbial safety and preservation of fresh

lettuce. Food Science and Biotechnology, 24(5), 1717-1724.

https://doi.org/10.1007/s10068-015-0223-8

Song, K., \& Milner, J. A. (2001). The influence of heating on the anticancer properties of garlic. The Journal of Nutrition, 131, 1054S-1057S

Srividya, A. R., Venkatesh, N., \& Vishnuvarthan, V. J. (2010). Nutraceutical as medicine. Pharmanest, 1(2), 132-145.

Surowsky, B., Schlüter, O., \& Knorr, D. (2014). Interactions of non-thermal atmospheric pressure plasma with solid and liquid food systems: A review. Food Engineering Reviews, 7(2), 82-108.

https://doi.org/10.1007/s12393-014-9088-5

Takai, E., Kitano, K., Kuwabara, J., \& Shiraki, K. (2012). Protein inactivation by low-temperature atmospheric pressure plasma in aqueous solution.

Plasma Processes and Polymers, 9(1), 77-82.

https://doi.org/10.1002/ppap.201100063

Thirumdas, R., Sarangapani, C., \& Annapure, U. S. (2014). Cold plasma: A novel non-thermal technology for food processing. Food Biophysics, 10(1), 1-11. https://doi.org/10.1007/s11483-014-9382-z

Thirumdas, R., Trimukhe, A., Deshmukh, R. R., \& Annapure, U. S. (2016) Functional and rheological properties of cold plasma treated rice starch. Carbohydrate Polymers, 157, 1723-1731.

https://doi.org/10.1016/j.carbpol.2016.11.050

Tiwari, B. K., O’Donnell, C. P., \& Cullen, P. J. (2009). Effect of non thermal processing technologies on the anthocyanin content of fruit juices. Trends in Food Science and Technology, 20(3-4), 137-145.

https://doi.org/10.1016/j.tifs.2009.01.058

Tresp, H., Hammer, M. U., Weltmann, K.-D., \& Reuter, S. (2013). Effects of Atmosphere composition and liquid type on plasma-generated reactive species in biologically relevant solutions. Plasma Medicine, 3(12), 45-55. https://doi.org/10.1615/PlasmaMed.2014009711

Van Heel, A. J., Montalban-Lopez, M., \& Kuipers, O. P. (2011). Evaluating the feasibility of lantibiotics as an alternative therapy against bacterial infections in humans. Expert Opinion on Drug Metabolism \& Toxicology, 7 , 675-680. https://doi.org/10.1517/17425255.2011.573478

Villa, T. G., \& Viñas, M. (2016). New weapons to control bacterial growth. New Weapons to Control Bacterial Growth, 1-556.

https://doi.org/10.1007/978-3-319-28368-5

Wang, R. X., Nian, W. F., Wu, H. Y., Feng, H. Q., Zhang, K., Zhang, J., \& Zhu, W. D. (2012). Atmospheric-pressure cold plasma treatment of contaminated fresh fruit and vegetable slices: Inactivation and physiochemical. European Physical Journal D, 66(276), 1-7.

https://doi.org/10.1140/epjd/e2012-30053-1

Weltmann, K. D., Brandenburg, R., Von Woedtke, T., Ehlbeck, J., Foest, R., Stieber, M., \& Kindel, E. (2008). Antimicrobial treatment of heat sensitive products by miniaturized atmospheric pressure plasma jets (APPJs). Journal of Physics D: Applied Physics, 41, 1-6.

https://doi.org/10.1088/0022-3727/41/19/194008

Xu, D., Liu, D., Wang, B., Chen, C., Chen, Z., Li, D., ... Kong, M. G. (2015). In situ $\mathrm{OH}$ generation from $\mathrm{O} 2-$ and $\mathrm{H} 2 \mathrm{O} 2$ plays a critical role in plasma-induced cell death. Plos One, 10(6), e0128205.

https://doi.org/10.1371/journal.pone.0128205 
Xu, L., Garner, A. L., Tao, B., \& Keener, K. M. (2017). Microbial inactivation and quality changes in orange juice treated by high voltage atmospheric cold plasma. Food and Bioprocess Technology, 10, 1778-1791. https://doi.org/10.1007/s11947-017-1947-7

Xu, Y., Tian, Y., Ma, R., Liu, Q., \& Zhang, J. (2016). Effect of plasma activated water on the postharvest quality of button mushrooms, Agaricus bisporus. Food Chemistry, 197, 436-444.

https://doi.org/10.1016/j.foodchem.2015.10.144

Yang, S. C., Lin, C. H., Sung, C. T., \& Fang, J. Y. (2014). Antibacterial activities of bacteriocins: Application in foods and pharmaceuticals. Frontiers in Microbiology, 5, 1-10. https://doi.org/10.3389/fmicb.2014.00241

Yeon, M., Jo, S., \& Min, S. C. (2017). Mandarin preservation by microwave-powered cold plasma treatment. Innovative Food Science and Emerging Technologies, 39, 25-32. https://doi.org/10.1016/j.ifset.2016.10.021

Yildirim, E. D., Gandhi, M., Fridman, A., Sun, W., Güçeri, S., \& Sun, W. (2008). Plasma assisted decontamination of biological and chemical agents. In S. Güçeri \& A. Fridman (Eds.). Dordrecht, Netherlands: Springer. https://doi.org/10.1007/>978-1-4020-8439-3_17

Zhang, B., Chen, L., Li, X., Li, L., \& Zhang, H. (2015). Understanding the multi-scale structure and functional properties of starch modulated by glow-plasma: A structure-functionality relationship. Food Hydrocolloids, 50, 228-236. https://doi.org/10.1016/j.foodhyd.2015.05.002

Zhang, J., Yuan, L., Liu, W., Lin, Q., Wang, Z., \& Guan, W. (2017). Effects of UV-C on antioxidant capacity, antioxidant enzyme activity and colour of fresh-cut red cabbage during storage. International Journal of Food Science and Technology, 52(3), 626-634. https://doi.org/10.1111/ijfs.13315

Zhang, L., \& Gallo, R. L. (2016). Antimicrobial peptides. Current Biology, 26(1), R14-R19. https://doi.org/10.1016/j.cub.2015.11.017

Zhang, L., Rozek, A., \& Hancock, R. E. W. (2001). Interaction of cationic antimicrobial peptides with model membranes. Journal of Biological Chemistry, 276(38), 35714-35722. https://doi.org/10.1074/jbc.M104925200

Zhao, J., Ge, L. Y., Xiong, W., Leong, F., Huang, L. Q., \& Li, S. P. (2016).

Advanced development in phytochemicals analysis of medicine and food dual purposes plants used in China (2011-2014). Journal of Chromatography A, 1428(42), 39-54. https://doi.org/10.1016/j.chroma.2015.09.006

Zhu, F. (2017). Plasma modification of starch. Food Chemistry, 232, 476-486. https://doi.org/10.1016/j.foodchem.2017.04.024

Ziuzina, D., Patil, S., Cullen, P. J., Keener, K. M., \& Bourke, P. (2014) Atmospheric cold plasma inactivation of Escherichia coli, Salmonella enterica serovar Typhimurium and Listeria monocytogenes inoculated on fresh produce. Food Microbiology, 42, 109-116.

https://doi.org/10.1016/j.fm.2014.02.007 